IZA DP No. 10342

Labor-Market Scars When Youth Unemployment Is Extremely High: Evidence from Macedonia

Marjan Petreski

Nikica Mojsoska-Blazevski

Marcelo Bergolo

November 2016 


\title{
Labor-Market Scars When Youth Unemployment Is Extremely High: Evidence from Macedonia
}

\author{
Marjan Petreski \\ University American College Skopje \\ University American College Skopje \\ Marcelo Bergolo \\ IECON-UDELAR and IZA \\ Discussion Paper No. 10342 \\ November 2016 \\ IZA \\ P.O. Box 7240 \\ 53072 Bonn \\ Germany \\ Phone: +49-228-3894-0 \\ Fax: +49-228-3894-180 \\ E-mail: iza@iza.org
}

Nikica Mojsoska-Blazevski

\begin{abstract}
Any opinions expressed here are those of the author(s) and not those of IZA. Research published in this series may include views on policy, but the institute itself takes no institutional policy positions. The IZA research network is committed to the IZA Guiding Principles of Research Integrity.

The Institute for the Study of Labor (IZA) in Bonn is a local and virtual international research center and a place of communication between science, politics and business. IZA is an independent nonprofit organization supported by Deutsche Post Foundation. The center is associated with the University of Bonn and offers a stimulating research environment through its international network, workshops and conferences, data service, project support, research visits and doctoral program. IZA engages in (i) original and internationally competitive research in all fields of labor economics, (ii) development of policy concepts, and (iii) dissemination of research results and concepts to the interested public.
\end{abstract}

IZA Discussion Papers often represent preliminary work and are circulated to encourage discussion. Citation of such a paper should account for its provisional character. A revised version may be available directly from the author. 
IZA Discussion Paper No. 10342

November 2016

\section{ABSTRACT \\ Labor-Market Scars When Youth Unemployment Is Extremely High: Evidence from Macedonia*}

The objective of this study is to assess how the duration of the unemployment spell of Macedonia youth affects later employment (the employment 'scarring' effect) and wage outcomes (the wage 'scarring' effect). To that end, we first devise a model in which the unemployment spell is determined by individual and household characteristics and work attitudes and preferences. Discrete-time duration method is used to estimate this model. Then, we rely on a standard employment and Mincer earnings functions. We repeatedly impute missing wages to address the selection on observables, and use the regional unemployment rate when individual finished school as an instrument to mitigate the selection on unobservables. The School to Work Transition Survey 2012 is used. Results robustly suggest a presence of employment scar as those young persons who stay unemployed over a longer period of time were found to have lower chances to find a job afterwards. On the other hand, the study does not provide evidence for the existence of the wage scar.

JEL Classification: E24, J24, J64

Keywords: employment scarring, wage scarring, extremely high unemployment, Macedonia

Corresponding author:

Marcelo Bérgolo

Instituto de Economía (IECON)

Department of Economics

Universidad de La República

1375 Joaquín Requena

Montevideo 11200

Uruguay

E-mail: mbergolo@iecon.ccee.edu.uy

\footnotetext{
* This research work was carried out with financial and scientific support from the Partnership for Economic Policy (PEP) (www.pep-net.org) with funding from the Department for International Development (DFID) of the United Kingdom (or UK Aid), and the Government of Canada through the International Development Research Center (IDRC). The authors are also grateful to Manuel Paradis and Marjorie Alain for technical support and guidance.
} 


\section{Introduction}

Costs of youth unemployment could be undoubtedly large. For the society, high youth unemployment rates (including large joblessness) diminish the potential contribution of youth to economic growth and development. They present a lost development and welfare potential. Studies show unemployment can cause social misbehavior of youth such as drug addiction, crime, extremist ideologies, etc. (Raphael and Winter-Ebmer, 2001; Fougère et al. 2009). For the individual, the direct cost of unemployment spell is expressed by the lost income (Gregg and Tominey, 2005) as well the long-term adverse effect onto future labor-market performance; the so-called "scarring" effects. Many studies find that unemployment spell early in the life of a young person reduces the probability of employment (the employment "scarring") as well wage prospects (the wage "scarring”) later in life (Arulampalam et al. 2001; Ryan, 2001; Gregg and Tominey, 2005; Fares and Tiongson, 2007; Cruces et al. 2012).1

The disadvantaged position of youth on the labor market is to a large extent rooted in their transition from school to work. The term "school-to-work transition" is a relatively newly-backed concept encompassing several long-standing issues related to education, employment, experience and training, and respective policies (Ryan, 2001). The school to work transition is commonly defined as the period between the end of the mandatory schooling and the attainment of a stable job. The theoretical foundations establish that during this period skills and knowledge may erode, undermining employment and wage prospects (Becker, 1964). Even if this is not the case, long spell of unemployment may signal lower productivity and hence impair youth chances in the job-application process (Spence, 1973).

However, little is known about this critical process of transition from school to the working life in the developing countries, let alone in those of them with extremely high unemployment. Different labormarket institutions and contexts, wage negotiation processes and trade unions, labor norms, socioeconomic context and culture, large informal employment, may affect the school to work transition process. In particular, in such contexts, the unemployment spells early in life may not signal eroded human capital, but rather be accepted as normal, hence scars may be weaker or absent.

The objective of this study is twofold: first, to investigate the determinants of the duration of unemployment spell of youth in a developing context; and second, to assess how the unemployment spell duration affects later employment (the employment 'scarring' effect) and wage outcomes (the wage 'scarring' effect). In investigating the two issues, we make a special reference to gender, in order to understand if females as a disadvantaged group compared to men, face distinct scars.

To pursue our objectives, we focus on Macedonia. Macedonia has an unemployment rate of $26 \%$ and youth unemployment rate of 53\%. The average time of unemployment between finishing school and

\footnotetext{
${ }^{1}$ While the paper does not aim to investigate the underlying causes for the youth unemployment, Brada et al. (2014) provide a very good summary of the main theories and determinants of youth unemployment.
} 
obtaining a stable job is about six years. Labor market flexibilised lately, but wages are mostly nonnegotiable, especially for the entry levels. Trade unions are weak. Informal sector is large, about 25\% of the total economy, hence potentially providing some job opportunities for youth. We first devise a model in which the unemployment spell is determined by individual and household characteristics and work attitudes and preferences. Discrete-time duration method is used to estimate this model, given the dependent variable measures the time elapsed until the person got a job or until now if he-she is still unemployed. Then, we rely on a probit function to assess the employment scar and a Mincer earnings function to assess the wage scar. We repeatedly impute missing wages to address the selection on observables (as in Olivetti and Petrongolo, 2008), and use the regional unemployment rate when individual finished school as an instrument to mitigate the potential endogeneity of the unemployment spell duration with respect to both, employment and wage today. The School to Work Transition Survey 2012 is used.

Results suggest that it is working attitudes and preferences - like career orientation, pursuance of internship, and the reservation wage - that most affect the unemployment spell duration. Household factors, prevalently father's education and family welfare are also found important, while individual factors have limited role to play. Results robustly suggest a presence of employment scar: those young persons who stay unemployed over a longer period of time have lower chances to find a job afterwards. The employment scar is not found different between genders. Hence, it is the human capital theory that likely drives the scar in Macedonia. On the other hand, the study does not provide evidence for the existence of the wage scar, reckoning with the notion that employers no longer consider long unemployment spells detrimental for the wage in high unemployment context.

Designed this way, the present paper makes a couple of contributions to the current scarce of knowledge. First, to our knowledge, it is among the few papers investigating the labor-market scars for a transition economies in a high-unemployment context. In that respect, findings may shed further light on the potential distinct patterns of scarring on the labor market in developing economies in general. Second, the paper is the first to utilize the School-to-Work-Transition Survey 2012, which has been compiled and presented by the ILO only recently. Third, the paper uses novel techniques for estimating the wage function: the repeated imputations technique, so as to overcome the selection on observables. While such approach has been used in investigating other labor-market phenomena (e.g. Olivetti and Petrongolo, 2008; Petreski et al. 2014), it is the first attempt to utilize its advantages in the analysis of youth wages. Finally, in country with severe youth unemployment rates, the paper would benefit policymakers in devising active labor market programs specifically designed for youth, including but not limited to internships, traineeships, subsidies, programs of quick start, career counselling and guidance and the like. Based on the results of this study, policies that focus on the gender perspective may not be a first-order issue for our case. 
The study is structured as follows. Section 2 provides an overview of the related literature and portrays the potential reasons of different pattern of scarring in high unemployment context. Section 3 offers brief stylized facts about the Macedonian labor market. Section 4 presents the data we use. Section 5 extensively discusses the economic models pursued and the methodological issues. Section 6 presents the results and offers further discussion. Section 7 concludes and offers some policy advice.

\section{Literature overview}

\subsection{Theoretical background}

Theoretical explanations for the presence of the labor-market scars are laid down in two main theories: the human capital theory of Garry Backer (1964) and the signaling theory (Spence, 1973). According to the first, employment and wage scars are related to the depreciation of skills and knowledge an individual possess following an unemployment spell. This loss of skills consequently reduces the workers' productivity and hence leads to lower labor-market returns. The other explanation backed up in the signaling theory suggests that in presence of information asymmetry, employers face uncertainty about workers' productivity when hiring. Therefore, they use statistical-screening device in the hiring process, based on the group to which the worker belongs (in terms of age, gender, education, ethnicity, family background, etc.) (Lockwood, 1991; Kollmann, 1994; Lupi and Ordine, 2002; Mooi-Reci and Ganzeboom, 2014). Unemployment spell (its frequency and/or duration) of a worker, in this setting, is signaling lower productivity, and is therefore penalized by lower employment probability and wage. There might be though some supply-side explanation for the existence of this negative duration dependence such that workers search efforts fade away, they "inherit" certain behavior from the unemployment spell that makes them less productive, and/or that skills and knowledge deteriorate (Lockwood, 1991). This stigma or signaling effect seems to be the highest among the most-skilled workers, as these are least likely (expected) to experience unemployment.

Related to the gender, human capital theory predicts that the loss of human capital between genders is not same. Females, due to child rearing (but also household duties, care of older family members) tend to accumulate less work experience than males. Hence, women should experience lower re-employment wages compared to males (Mooi-Reci and Ganzeboom, 2014). This implies that if human capital theory drives the employment scarring, after controlling for the individual characteristics, the extent of scarring should be about the same for both genders. On the contrary, if signaling and the associated stigma is the underlying explanation behind the employment scarring, it is likely that certain disadvantaged groups (including females) face larger scars.

\subsection{Review of the empirical literature}

Most studies empirically confirm the presence of the employment scar, while the literature is not that unanimous regarding the wage scar. For instance, Gregg (2001) finds that the early labor-market experience of young persons, family context, educational attainment and behavioral traits all affect 
future employment probabilities. Gregory and Jukes (2001) find that a one-year spell of unemployment brings a wage penalty of 10 percentage points for British men. Gregg and Tominey (2005) find a wage scar from early unemployment experience in Britain of 12-15\% at age of 42. Cockx and Picchio (2012) focus on young individuals who are already long-term unemployed in Belgium and find that prolonging unemployment significantly reduces employment probability, but not the wage; the effect is mainly the result of negative signaling. The study of Nilsen and Reiso (2011) also focuses on young individuals in Norway and, using propensity score matching, it finds long-term scars from unemployment (about 10 p.p. higher chance of being unemployed at year five), which then decreases over time (to about 5 p.p. in year eight and onwards). They do not find any gender difference.

The methodological approaches used in the previous studies differ mainly depending on the type of available data and thus, in the way that they address the selection in observables on the scarring estimates. For instance, Gregg (2001) uses a rich dataset of a cohort (born in March 1958), over a long time span, which includes both labor market but also some other valuable information about individuals (including ability and behavioral tests) and families. They use IV approach, with local unemployment rate at the first entry into the labor market (at age of 16) as their instrument. They, though, acknowledge that the use of instrumental variables with a limited dependent variable (for which they apply Tobit model) is not straightforward. They adjust the standard errors in the face of IV estimation based on the Amemiya's Centralized Least Squares (AGLS). Arulampalam et al. (2001) work with a British household panel data and use a random-effects probit model. They apply a two-step procedure where IVs are used in the first step to estimate a reduced form model for the initial observation. In the second step, a probit model is used with random effects to control for unobserved heterogeneity. These and other similar studies try to separate the effect of heterogeneity2 and duration dependence (past unemployment affecting current unemployment), by making assumptions about the likely distribution of the heterogeneity. The main line of critique to these approaches is that assumptions made about the functional form are very strong (for instance, Lancaster, 1990). Cockx and Picchio (2012) use multivariate duration model that controls for selection on observables and unobservables, and allows for lagged state and duration dependence. They integrate the analysis of wages within this framework. Their data source is an administrative panel of 14,660 young persons who in 1998 were still unemployed (nine months after completing their education). They are able to construct quarterly labor market histories for those individuals for the period up to 2002.

Little is known about the labor-market scarring effects in developing countries. Many of them face different socio-economic environment, institutional framework, large grey economy and jobs, different culture and norms, and sometimes very high unemployment. Most of the research has been focused on

\footnotetext{
${ }^{2}$ Current unemployment could be determined by unobservable characteristics (heterogeneity) which lead to otherwise low exit probabilities, instead of past unemployment experience influencing current unemployment.
} 
tight labor market, and the underlying theories (either the human capital or the signaling) are also more suitable to such environments. In slack labor market where unemployment is widespread and socially accepted as "normal", the unemployment spell may not be considered as a signal of the worker's productivity, giving rise to lower or no employment and wage scar. Moreover, the large army of unemployed individuals does not even exert a downward pressure on wages. In those countries/regions, unemployment is less costly than in the slack labor markets (Lupi and Ordine, 2002). In the notion of the human-capital explanation for the existence of the labor-market scars, if unemployed are less educated and trained relative to employed and/or the quality of education is generally low (as in most developing countries), then unemployment spells do not bring large loss of human capital and skills.

Social behavior and attitudes towards unemployment may also be very different between countries/regions with high and low unemployment. Recently, the issue of culture, norms and attitudes gains increasing attention in the economics and management. Fernandez and Fogli (2009) and Blau et al. (2013), for instance, model the effect of culture on female labor supply and fertility decisions. There are studies that also examine the effect of culture on employment probability, but mainly focusing on the immigrants (for example, Nekby and Rödin, 2009). However, to our knowledge, there has been no attempt so far to examine the effect of culture in the scarring literature. In slack labor markets, one can expect that there is a greater tolerance and acceptance of unemployment which as well may break the link between the unemployment experience early in one's career and the subsequent labor-market experience. Institutional setup can play an important role for the scaring. For instance, if wage structure and wage negotiation system is not flexible, and wage levels are strongly prescribed by job position, then any worker that gets into a job will share the same wage as his/her colleague holding same or similar job position. In this type of setting, the previous unemployment experience can only have a trivial effect on the subsequent wage.

Large informal sectors, more common for developing countries, further confound the link between the unemployment spell and subsequent employment probability and wage. In particular, informally employed workers are likely to generate and upgrade their skills, and hence their human capital increases, but the signals that they send to employers likely do not include that information. More recently, the focus of the literature has been indeed extended to the type of the first job held by young workers as many of them in developing countries tend to start their employment history in an informal job. Expectations on this issue may well go into two distinct directions: i) informality early in career may extend informality later and negatively impact wages (Gasparini and Tornarolli, 2009); or ii) informal jobs may provide some training, networks and work experience to young workers hence improving their formal employment and wage potentials (Cunningham and Salvagno, 2011).

Studies related to developing countries are rare mainly due to lack of long-term panel data. Hence, methodological strategies in these cases are slightly different. Using pooled OLS, Cruces et al. (2012) find that an additional percentage point in the unemployment rate during youth leads to an increase of 
the adult normalized unemployment rate of 0.5 p.p. in Argentina and 0.9 p.p. in Brazil. They find wage scaring only in the case of Argentina. Cruces et al. (2012) use pseudo-panels which track birth cohorts and apply a cross-cohort differences as the main source of variability for identification, rather than relying on "different individual labor market experiences within a single cohort" (p. 2). Fares and Tiongson (2007) for Bosnia utilize longitudinal data from the Living Standards Measurement Survey (LSMS) but data cover a short time span of 2001-2004. They apply simple probability model of employment or unemployment where regressors are several observable characteristics and unemployment history. They estimate employment scarring for individuals who were unemployed in 2001, tracing them to 2004. They are also able to observe wages for those that were employed in 2004. They estimate the wage effect through a Mincer type regression (with included variables capturing the labor market experience in the previous three years), using OLS. They find a significant employment scar: young people that experienced joblessness in 2001 had 11\% greater probability of being unemployed and 30\% greater probability of being jobless (unemployed or inactive) in 2004 compared to their peers who were employed in 2001. They however did not find presence of wage scar.

Empirically, the study of Lupi and Ordine (2002) for Italy is so far the only study that examines the above issues in more details. In line with the expectations, they indeed find that the unemployment experience does not produce unemployment and wage scars in regions with high unemployment rates. In those regions majority of workers have experienced a period of unemployment and hence the unemployment spells do not necessarily signal low worker productivity: the adverse impact of unemployment experience is relatively low.

Overall, the literature suggests that high unemployment context could potentially weaker the link between the early unemployment experience and later labor-market outcomes.

\section{Characteristics of Macedonian labor market}

Labor market in Macedonian is confronted with serious challenges: high inactivity among the workingage population, low employment rates, high (involuntary) unemployment, and a large share of employment in the shadow economy. These problems are particularly aggravated for certain categories of workers, most prominently, young workers and females.

Figure 1 shows activity rates3 by different characteristics of the working-age population in Macedonia, Southeast Europe and the EU-28. About 65\% of the Macedonian population aged 15-64 was active in the labor market in 2015, which is comparable to the countries in the region, but lower than the EU-28 average by 7.3 percentage points (p.p.). Apparently, this large gap with the EU is created by the low participation of youth and females in Macedonia. Only one third of the young population is active in

\footnotetext{
${ }^{3}$ Share of active population in working-age population (15-64).
} 
the labor market, which is much lower than in the EU. In addition, activity is very low among loweducated individuals (42\%) where with the EU-28 is 22 p.p. This might point to a presence of barriers and/or disincentives for labor market activity of young people, females and low-educated individuals, as well as their social exclusion.

Figure 1 - Participation rates (aged 15-64) by individual characteristics, 2013

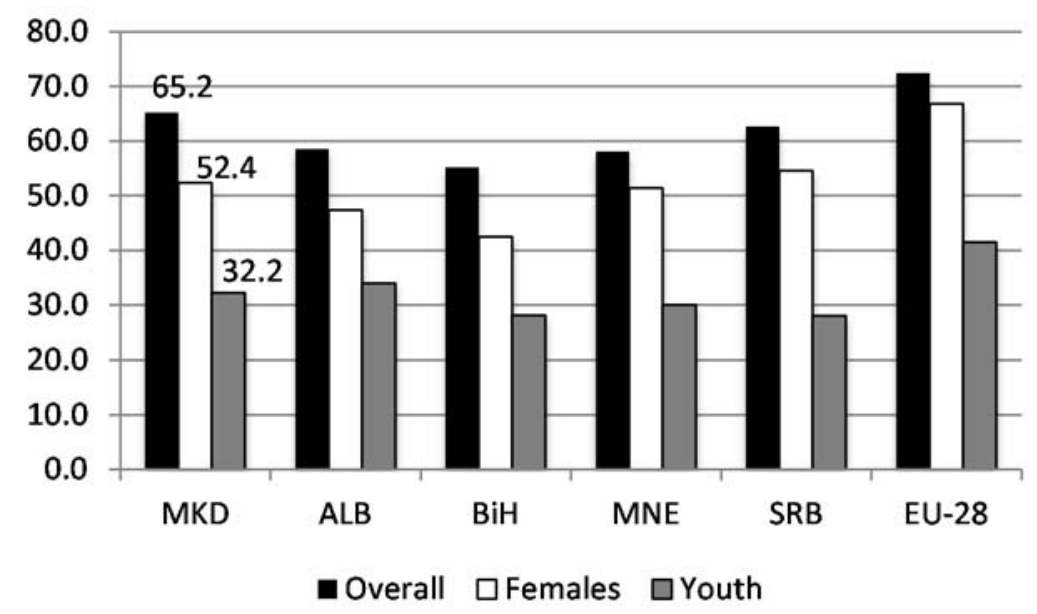

Source: KILM database of the ILO (ILO estimates); Eurostat database for EU-28.

In addition, only $41.6 \%$ of the working-age population (aged $15+$ ) in Macedonia were employed in 2015 (46\% of the population aged 15-64), which is comparable across the region, although much lower than the EU-28 average (Figure 2). Young workers in Macedonia face a very low employment rate: only 1 in 5 young persons have a job.

Figure 2 - Employment rates by individual characteristics, 2013

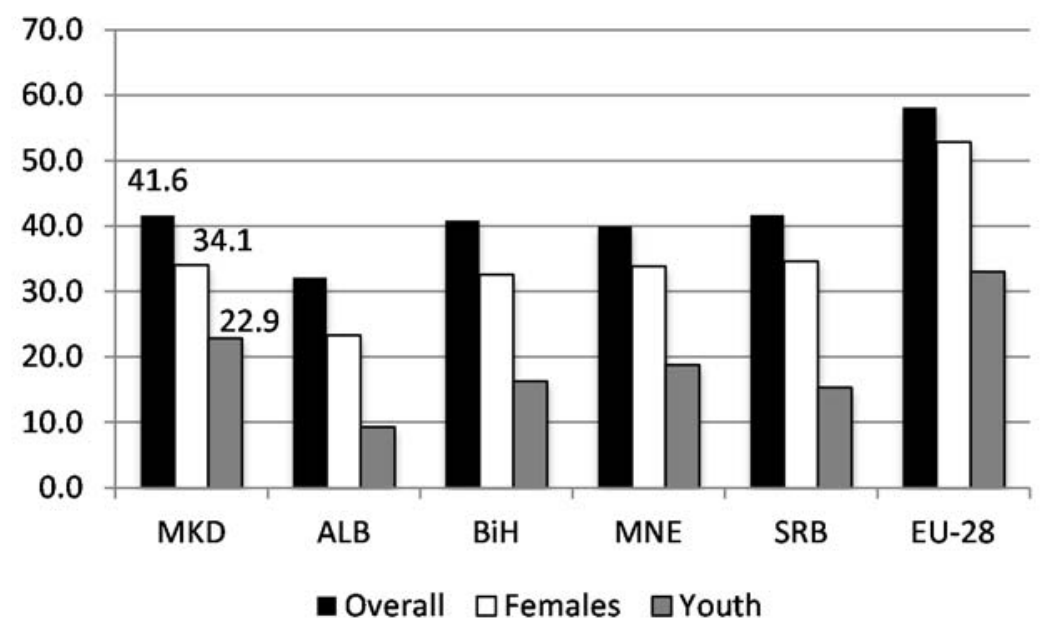

Source: KILM database of the ILO (ILO estimates); Eurostat database for EU-28. 
The unemployment rate in Macedonia in 2014 was 29\%, equally affecting both genders. It has been continuously declining in recent years (even during the Great Recession of 2008), although very modestly. It is higher even compared to the countries in the Southeast European region (except in Bosnia), and stands about 18 p.p. higher than the EU-28 average. Amid unemployment is generally high, young people and low-educated workers are particularly prone to unemployment.

The youth unemployment rate in 2014 (young workers aged 15-24) was 53\%, much higher than the EU-28 average of 22\% (although the youth unemployment in Greece and Spain increased at similar levels during the crisis). Besides low employment and high unemployment of young people, a large majority of them is also neither in education, employment or training (the so-called NEET). In 2014, one in every four young people aged 15-24 in Macedonia was out of education, employment or training. This NEET rate of $25 \%$ is double that of the EU countries (12, 4\%).

Table 1 provides some further evidence for the difficult position of young people in the Macedonian labor market. In particular, only 38\% of young people who completed their education managed to find a job in one to three years after exiting schooling. This is half the share in the EU countries, where 70\% of young people find a job in one to three years after exit from the education.

Table 1 - Share of young persons aged 15-34 that transited to employment 1-3 years after exit from education

\begin{tabular}{|lcccccc|}
\hline Macedonia & $\mathbf{2 0 0 9}$ & $\mathbf{2 0 1 0}$ & $\mathbf{2 0 1 1}$ & $\mathbf{2 0 1 2}$ & $\mathbf{2 0 1 3}$ & $\mathbf{2 0 1 4}$ \\
\hline EU-28 & $\mathbf{7 2 . 5}$ & $\mathbf{4 3 . 6}$ & $\mathbf{4 1 . 9}$ & $\mathbf{3 9 . 9}$ & $\mathbf{3 9 . 3}$ & $\mathbf{3 8 . 1}$ \\
\hline Greece & 61.6 & 54.6 & $\mathbf{7 1 . 5}$ & $\mathbf{7 0 . 2}$ & $\mathbf{6 9 . 9}$ & $\mathbf{7 0 . 3}$ \\
\hline Italy & 55.5 & 51.9 & 51.9 & 49 & 43.8 & 40.6 \\
\hline Spain & 60.7 & 56.5 & 57.1 & 52.4 & 48.9 & 54.3 \\
\hline Turkey & 48.9 & 51.2 & 52.7 & 52.9 & 54 & 55.5 \\
\hline Croatia & 70.2 & 64.6 & 57 & 53 & 48 & 56.1 \\
\hline Bulgaria & 65 & 57.4 & 53.5 & 59 & 60.8 & 58.9 \\
\hline Romania & 72.2 & 66.6 & 65.3 & 64.8 & 62.4 & 60.7 \\
\hline Portugal & 78 & 76.4 & 68.8 & 61.6 & 61.8 & 63.8 \\
\hline France & 69.4 & 70 & 70.3 & 68.8 & 67.7 & 66.3 \\
\hline Slovenia & 80.3 & 77.6 & 73.6 & 70.6 & 71.6 & 67.4 \\
\hline Hungary & 71.3 & 70.9 & 69.8 & 69.6 & 70.1 & 72.8 \\
\hline Poland & 75.9 & 74.1 & 73.2 & 71.2 & 71.2 & 73.3 \\
\hline Latvia & 64.4 & 59.4 & 66 & 68.7 & 75.2 & 74.8 \\
\hline Estonia & 60.1 & 60.8 & 70.2 & 70 & 72.7 & 76.3 \\
\hline Czech Rep. & 82.2 & 78.3 & 76.8 & 78.3 & 77.9 & 78.8 \\
\hline Switzerland & 85 & 85.9 & 84.1 & 85.7 & 82.9 & 85.7 \\
\hline Germany & 80.8 & 81.6 & 84.8 & 85 & 86.5 & 86.4 \\
\hline
\end{tabular}

Source: Eurostat database. 


\section{Data and sample description}

The study uses the School-to-Work-Transition Survey (SWTS) 2012. The data have been gathered within the ILO's project “Work4Youth”, under which a School to Work Transition Survey (SWTS) was designed to help learn more and better about the experience of young workers in the labor market after completing school. The SWTS is a household survey for young persons aged 15-29 years. It was implemented as an additional module to the Labor Force Survey (LFS). The survey provides a rich set of data for 28 target countries including Macedonia. The Macedonian survey is a representative sample of 2,544 young individuals aged 15-29. The dataset is very rich, containing detailed data on many issues, including personal characteristics of youth, family characteristics, perceptions of young people towards different things (for instance, work-related mobility, quality of jobs, reference wage, etc.). Although data are cross-sectional, they contain details on the education and employment history of an individual, hence involving time information.4

For this analysis, we dispose inactive persons aged 15-29 (dominant part of which are persons still in education, $52 \%$ of total sample), leaving our sample with 1,044 observations, still providing sufficient number of observations for efficient estimates. The variables utilized from the survey include individual characteristics: age, experience, education, gender, marital status; household-related characteristics: parents' education, number of children, household financial situation; and work preferences and attitudes: pursuance of internship during studies, carrier orientation during school and today, reservation wage and job search intensity. The definitions of all used variable could be found in Table 14, while descriptive statistics are given in Table 15, both in the Appendix.

Table 2 shows the individual characteristics of youth in our sample. Most of the young people belong in the age group 25-29 (45\%), 37\% are aged 20-24 and only 7\% 15-19. These age shares are almost equally distributed across genders. Youth population living in urban areas constitutes $52.8 \%$ of the total sample. Majority (71\%) are non-married but the marital status is not equally distributed between males (where only $21.3 \%$ are married) and females (where $40.4 \%$ are married).

\footnotetext{
${ }^{4}$ The predominant cross-section character of the data would likely enable calculation of short-run effects only.
} 
Table 2 - Distribution of youth population by age group, location, marital status and education

\begin{tabular}{|c|c|c|c|}
\hline & Total & Males & Females \\
\hline \multicolumn{4}{|c|}{ Age group } \\
\hline 15-19 & $6.9 \%$ & $6.7 \%$ & $7.0 \%$ \\
\hline $20-24$ & $37.2 \%$ & $38.2 \%$ & $35.7 \%$ \\
\hline $25-29$ & $55.9 \%$ & $55.1 \%$ & $57.3 \%$ \\
\hline \multicolumn{4}{|c|}{ Settlement } \\
\hline Urban & $52.8 \%$ & $50.4 \%$ & $56.4 \%$ \\
\hline Rural & $47.2 \%$ & $49.6 \%$ & $43.6 \%$ \\
\hline \multicolumn{4}{|c|}{ Marital status } \\
\hline Non-married & $71.0 \%$ & $78.7 \%$ & $59.6 \%$ \\
\hline Married & $29.0 \%$ & $21.3 \%$ & $40.4 \%$ \\
\hline \multicolumn{4}{|c|}{ Education } \\
\hline Primary or less & $18.8 \%$ & $20.7 \%$ & $15.9 \%$ \\
\hline Secondary & $58.8 \%$ & $64.1 \%$ & $50.8 \%$ \\
\hline Tertiary & $22.5 \%$ & $15.2 \%$ & $33.3 \%$ \\
\hline
\end{tabular}

Regarding the education structure of the sample, most of the young persons are holding secondaryschool diploma (59\%), 19\% have completed only primary education or less and $22.5 \%$ have tertiary education attainment. Young women are more likely to have completed tertiary education (33.3\% compared to $15.2 \%$ of males), but less likely to have only primary school attainment or less (15.9\% relative to $20.7 \%$ of males). Largest share of the surveyed youth in our sample (54\%) were employed in 2012 (see Figure 3).

Figure 3 - Distribution of youth population by main economic activity and gender

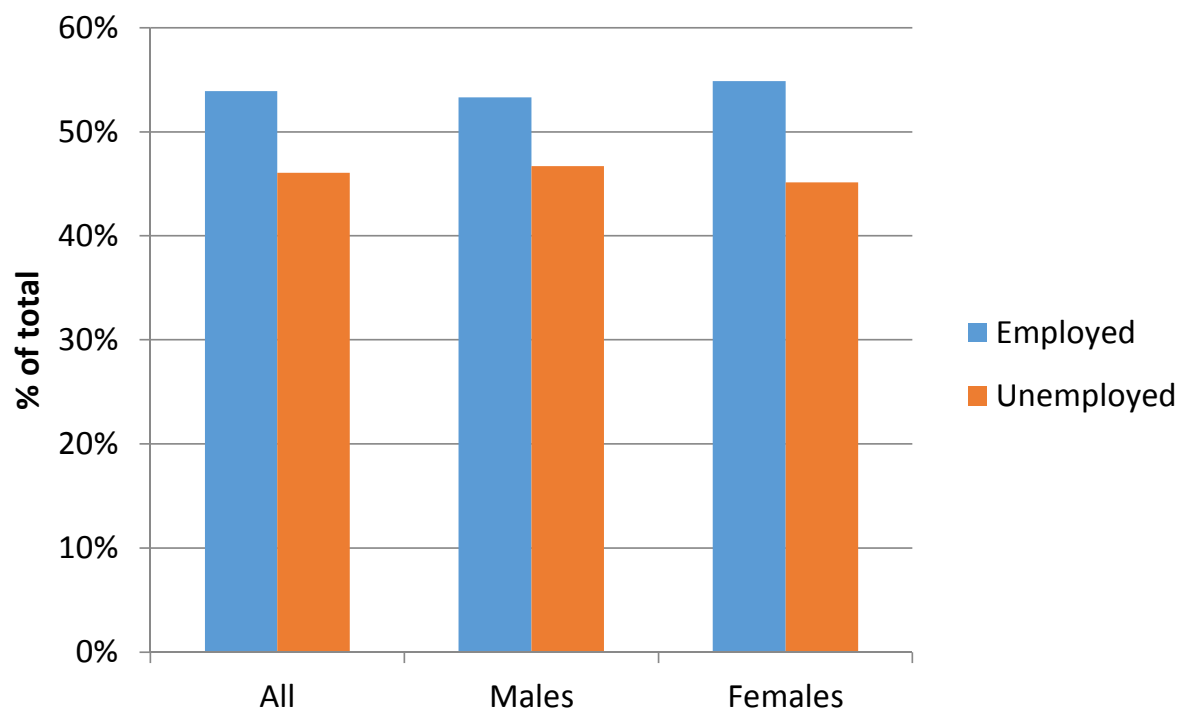

Source: SWT Survey 2012

Note: Sample weights used in calculations. 
Figure 4 presents the distribution of the youth unemployment spell duration in Macedonia. This is the key variable in this paper; it is an ordered variable ranging from $1=$ no unemployment spell to $8=\mathrm{a}$ spell of two and more years. It has been created by merging two questions available in the survey: "For how long have you been seeking for a job before you have found the current one?” and "For how long are you now without a job and have been actively search for such?” As the two are mutually exclusive, the aggregate unemployment spell duration variable has been created by their simple sum. It disaggregates it by employment status: those who are unemployed, so they still seek employment (in the statistical jargon, they are right censored) versus those who are employed and hence the unemployment spell duration refers to the unemployment length before the current job. In the total sample, $97.8 \%$ of the individuals experienced at least some unemployment spell (i.e., a spell of at least less than a week). Within those, 46.1 p.p. belong to those who are still searching for a job; while 51.7 p.p. belong to those who already got employment. The remaining part (2.2\%) are those who got employment immediately (or started working even before graduation) and those who are still in education but work.

Interestingly, those who are still unemployed youth are predominantly long-term unemployed, i.e. search for a job for more than a year (37\%). Conversely, those who work are somehow more evenly distributed, although slightly polarized: $8.9 \%$ searched for a job for less than a week, while $15.6 \%$ for two and more years.

\section{Figure 4 - Unemployment spell in Macedonia}

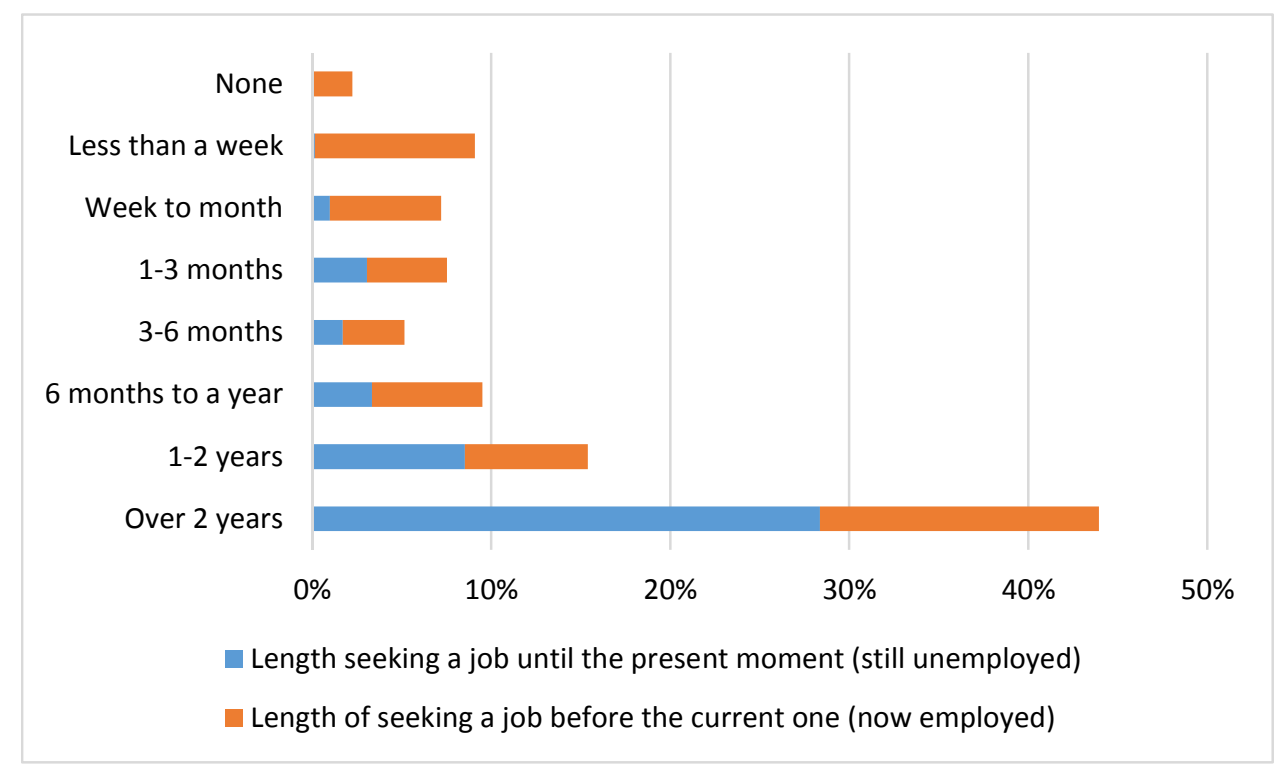

Source: SWT Survey 2012.

Note: Sample weights used in calculations. 
Figure 5 splits the sample by gender: the distribution of the unemployment spell duration portrays the same picture as on Figure 4, although the incidence of unemployment spells longer than 2 years is higher among males.

Figure 5 - Unemployment spell by gender (male - left; female - right)

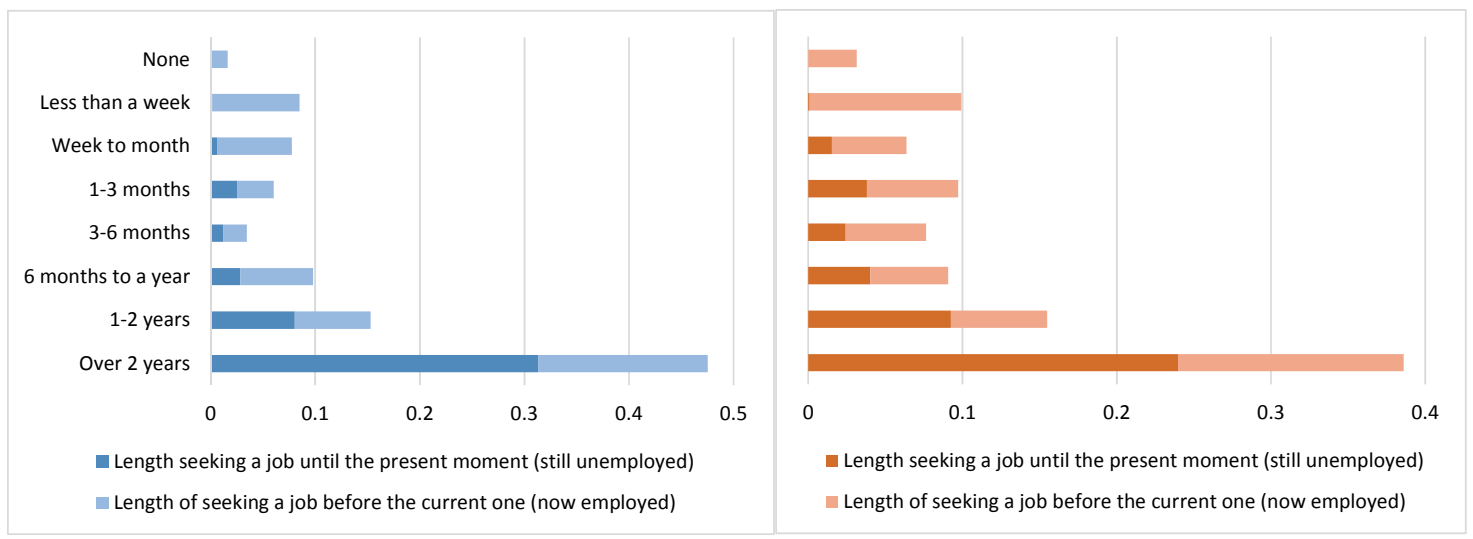

Source: SWT Survey 2012.

Note: Sample weights used in calculations.

Table 3 presents the distribution of the unemployment spell for key demographic divisions: by age, experience and education, as well for a gender division. The long-term unemployment, especially the one of over 2 years, is more prevalent among the older part of the youth, as well dominant among those lacking work experience. For those with at least some prior experience, the unemployment spell distribution is fairly even among categories. Expectedly, long-term unemployed with tertiary education are less than half those with primary or secondary education, at the expense of the shorter spells. Observed difference by gender is, in general, low and statistically insignificant. 
Table 3 - Unemployment spell duration and some demographics

\begin{tabular}{|c|c|c|c|c|c|c|c|}
\hline \multirow[b]{2}{*}{$\begin{array}{l}\text { Unemployment } \\
\text { spell duration }\end{array}$} & \multicolumn{2}{|c|}{ Age } & \multicolumn{2}{|c|}{ Experience } & \multicolumn{3}{|c|}{ Education } \\
\hline & $\begin{array}{l}\text { Below } \\
25\end{array}$ & $\begin{array}{c}\text { Above } \\
25\end{array}$ & Without & With & Primary & Secondary & Tertiary \\
\hline None & $1.3 \%$ & $3.0 \%$ & $2.4 \%$ & $1.7 \%$ & $1.2 \%$ & $1.4 \%$ & $5.5 \%$ \\
\hline Less than a week & $10.1 \%$ & $8.3 \%$ & $9.1 \%$ & $9.1 \%$ & $18.5 \%$ & $7.2 \%$ & $6.0 \%$ \\
\hline Week to month & $8.5 \%$ & $6.2 \%$ & $6.6 \%$ & $9.8 \%$ & $6.7 \%$ & $7.7 \%$ & $6.3 \%$ \\
\hline 1-3 months & $8.5 \%$ & $6.7 \%$ & $6.0 \%$ & $13.8 \%$ & $5.8 \%$ & $5.7 \%$ & $13.7 \%$ \\
\hline 3-6 months & $6.2 \%$ & $4.4 \%$ & $3.6 \%$ & $11.6 \%$ & $1.0 \%$ & $5.1 \%$ & $8.7 \%$ \\
\hline 6 months to a year & $7.8 \%$ & $10.8 \%$ & $7.5 \%$ & $18.1 \%$ & $7.4 \%$ & $7.3 \%$ & $16.9 \%$ \\
\hline 1-2 years & $19.3 \%$ & $12.3 \%$ & $14.5 \%$ & $19.1 \%$ & $9.7 \%$ & $15.8 \%$ & $19.1 \%$ \\
\hline \multirow[t]{2}{*}{ Over 2 years } & $38.4 \%$ & $48.3 \%$ & $50.4 \%$ & $16.8 \%$ & $49.7 \%$ & $49.8 \%$ & $23.8 \%$ \\
\hline & \multicolumn{7}{|c|}{ Males } \\
\hline None & $2.9 \%$ & $3.2 \%$ & $3.3 \%$ & $2.1 \%$ & $1.9 \%$ & $1.9 \%$ & $5.7 \%$ \\
\hline Less than a week & $12.7 \%$ & $8.0 \%$ & $10.0 \%$ & $11.6 \%$ & $14.3 \%$ & $10.7 \%$ & $7.7 \%$ \\
\hline Week to month & $8.2 \%$ & $7.5 \%$ & $7.0 \%$ & $11.2 \%$ & $6.5 \%$ & $8.2 \%$ & $7.8 \%$ \\
\hline 1-3 months & $9.3 \%$ & $8.9 \%$ & $8.1 \%$ & $13.1 \%$ & $4.3 \%$ & $6.7 \%$ & $16.2 \%$ \\
\hline 3-6 months & $4.6 \%$ & $3.3 \%$ & $3.0 \%$ & $8.1 \%$ & $2.2 \%$ & $3.3 \%$ & $6.2 \%$ \\
\hline 6 months to a year & $6.9 \%$ & $9.4 \%$ & $6.8 \%$ & $13.4 \%$ & $7.6 \%$ & $6.0 \%$ & $12.5 \%$ \\
\hline 1-2 years & $17.3 \%$ & $12.7 \%$ & $13.5 \%$ & $21.1 \%$ & $8.7 \%$ & $14.4 \%$ & $19.3 \%$ \\
\hline \multirow[t]{2}{*}{ Over 2 years } & $38.1 \%$ & $47.1 \%$ & $48.3 \%$ & $19.5 \%$ & $54.5 \%$ & $48.8 \%$ & $24.8 \%$ \\
\hline & \multicolumn{7}{|c|}{ Females } \\
\hline None & $4.0 \%$ & $0.8 \%$ & $2.8 \%$ & $0.6 \%$ & $2.0 \%$ & $1.3 \%$ & $5.4 \%$ \\
\hline Less than a week & $12.7 \%$ & $7.1 \%$ & $9.8 \%$ & $10.1 \%$ & $16.3 \%$ & $10.0 \%$ & $5.8 \%$ \\
\hline Week to month & $8.7 \%$ & $6.0 \%$ & $6.2 \%$ & $11.6 \%$ & $9.3 \%$ & $7.6 \%$ & $5.4 \%$ \\
\hline 1-3 months & $6.2 \%$ & $7.0 \%$ & $5.9 \%$ & $9.4 \%$ & $4.0 \%$ & $5.5 \%$ & $10.9 \%$ \\
\hline 3-6 months & $6.3 \%$ & $5.1 \%$ & $4.8 \%$ & $9.2 \%$ & $2.8 \%$ & $5.4 \%$ & $8.1 \%$ \\
\hline 6 months to a year & $9.8 \%$ & $8.7 \%$ & $6.5 \%$ & $19.9 \%$ & $3.4 \%$ & $9.3 \%$ & $12.4 \%$ \\
\hline 1-2 years & $16.8 \%$ & $9.3 \%$ & $12.1 \%$ & $16.4 \%$ & $7.7 \%$ & $11.6 \%$ & $19.3 \%$ \\
\hline Over 2 years & $35.5 \%$ & $55.9 \%$ & $52.0 \%$ & $22.8 \%$ & $54.6 \%$ & $49.3 \%$ & $32.6 \%$ \\
\hline
\end{tabular}

Figure 6 presents the wage distribution by gender and by unemployment spell. The wage is represented through the log of the gross hourly wage of each person for whom the wage is known/non-missing. Females are more exposed to low wages (at the left-hand side of the wage distribution, resulting in a negative gender wage gap; see Petreski et al. 2014), albeit the peak of their wage distribution is similar to that of males (Figure 6, left). Though, females are also slightly more represented at the high-wage end/tale. On the other hand, no differences may be observed when wage is analyzed across the unemployment spell durations (Figure 6, right), except in the peaks of the curves, whereby the peak goes down as the unemployment duration increases. 
Figure 6 - Wage distribution by gender (left) and unemployment spell duration (right)
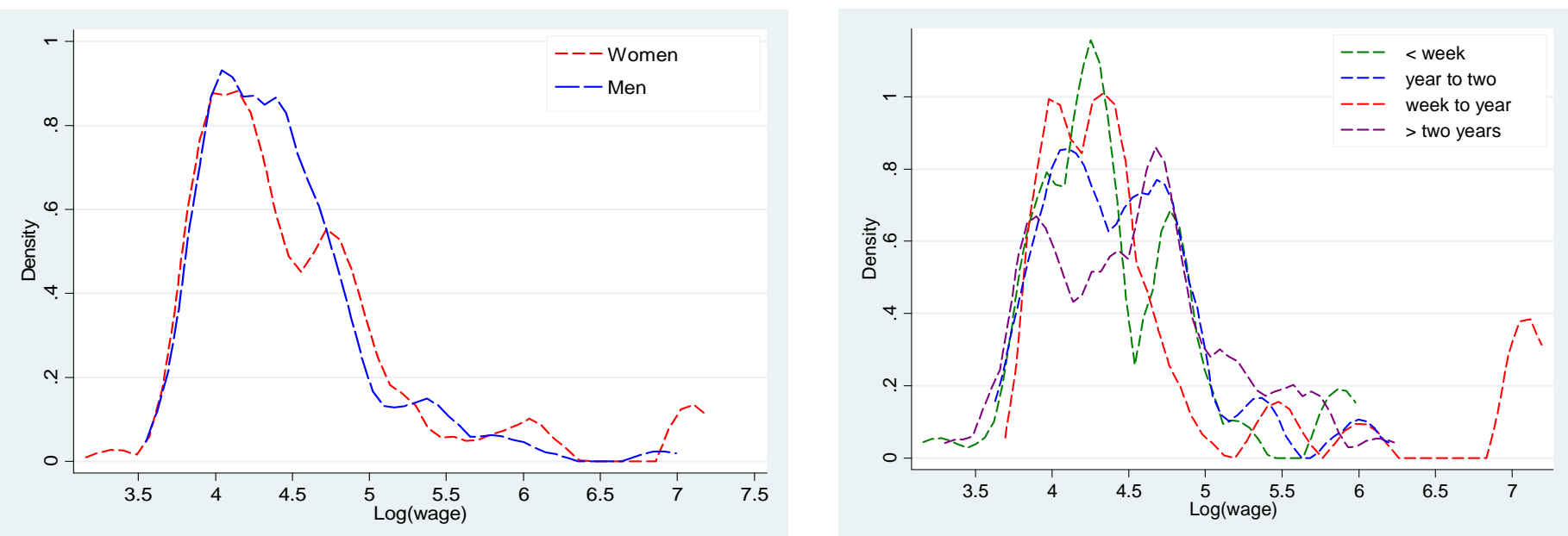

Source: SWT Survey 2012.

Note: Sample weights used in calculations. Unemployment spell durations are squeezed in four out of eight possible categories, due to the small number of observations.

\section{Empirical strategy}

The methodological concept behind this research is composed of two phases. In order to investigate the determinants of the unemployment spell, we first present a model of the unemployment spell. To investigate the scarring effect of youth unemployment spells, then, we model employment and earnings as functions of the unemployment spell.

\subsection{Unemployment spell model}

The determinants of the unemployment spell reduce to individual characteristics, socio-economic condition (or the household characteristics); and work preferences and attitudes. Hence, we set the regression as follows:

dur_unemp $_{i}=\alpha_{1}+\beta_{1 j} \sum$ indiv $_{j i}+\gamma_{1 j} \sum$ socio $_{j i}+\delta_{1 j} \sum w p a_{j i}+\vartheta r e g_{-} u n_{-} e d u_{i}+\varepsilon_{i}$

Whereby dur_unemp $p_{i}$ measures the time elapsed since individual i became unemployed, i.e. exited education but did not find a job immediately, or exited a job and found another after a period of searching or still searching for another. It is an ordered variable ranging from 1 = no unemployment spell to 8 = a spell of two and more years. For the purpose of the modelling, a dummy variable has been created also, to distinguish the cases where the variable is censored (the person is still searching for a job) out of those where it is not censored (the person is already in employment).

$\sum$ indiv $_{\mathrm{ji}}$ stands for a set $\mathrm{j}$ of individual characteristics of person $\mathrm{i}$, as follows: age, experience, gender, education; and marital status; $\sum$ socio $_{\mathrm{ji}}$ stands for a set $\mathrm{j}$ of socio-economic characteristics of the household: number of children in the household; the educational levels of the parents; and the financial 
situation of the household; $\sum w_{p a} a_{\mathrm{ji}}$ stands for a set $\mathrm{j}$ of working preferences and attitudes: the career attitude during schooling and now; pursuance of internship during schooling; the log reservation wage; and the search intensity (the number of applications for jobs before employment or before the moment of the interview).

reg_un_edu $u_{i}$ measures the unemployment rate at the regional level at the time when person i exited school. The presence of this variable should capture the local labor-market conditions at the time the person finished schooling, but is also important to serve exclusion restriction in our next regressions, as we discuss in Section 5.2. $\varepsilon_{\mathrm{i}}$ is the standard error term which is assumed to be well-behaved. Note that (1) will be estimated separately for males and females, as we opt to make a special reference to gender. There are two important econometric challenges in estimating (1), mainly derived from the character of the dependent variable. The first econometric challenge is that the dependent variable is a 'duration' variable. Hence, using a linear model may be problematic in a couple of veins: i) unemployment duration is usually not normally distributed, especially in the Macedonian data where we have a significant portion of youth with long spells (implying left-skewness); ii) some predictions from (1) may be negative, which is unrealistic for the unemployment spell; and iii) OLS would not make a distinction between cases where the unemployment spell still lasts versus the cases where it terminated (and the person is now employed). The second econometric challenge is that in our survey, our duration of unemployment variable is grouped in seven categories, rather than providing the actual duration in units of time.

To overcome these problems, we use the class of duration models (Kiefer 1988; Hensher and Mannering 1994), and, in particular, the discrete-time duration models. A neat introduction in duration models could be found in Hosmer et al. (2008). Duration models - or survival models - typically focus on timeto-event data. In the most general sense, they consist of techniques for positive valued random variables, such as the time to employment, in our case, called the "survival time”. Typically, survival data are not fully observed, but rather are censored. Censoring that is random and non-informative is usually required in order to avoid bias in a survival analysis.

The dependent variable - duration of unemployment - is composed of two parts: the time to employment and the employment status, i.e. if employment occurred or not. Hence, the two functions can be estimated dependent on time: the survival and hazard functions. The former gives, at any time point, the probability of surviving (staying in unemployment) up to that moment; the latter gives the potential that employment will happen, per time unit given the person survived up to that moment.

Finally, as our dependent variable is rather discrete - grouped into seven intervals, each specifying certain unemployment duration - we utilize the discrete-time duration models. Box-Steffensmeier and Jones (2004, p.69) provide a textbook explanation on this sub-group of duration models, while a neat application could be read in Muthén and Masyn (2005). We will be able to analyze discrete-time data 
using logistic regression with indicator variables for each of the unemployment duration periods. Such methodological approach should enable capturing the effects of previous unemployment duration on the current unemployment probability (duration dependence), leaving aside the effect of unobserved heterogeneity.

There is one additional methodological concern, though. Namely, the dependent variable is created out of questions which are retrospective in nature, i.e. ask the respondent for information related to past events. As Pina-Sánchez et al. (2013) note, the answers to such question face the potential of a measurement error due to memory loss in answering the unemployment duration question. The aspect is not further pursued in this analysis, for the following data-related reasons: our unemployment duration variable is measured in eight categories rather than in months suggesting that the likelihood of incorrect answer is reduced; and our unemployment-duration variable is left skewed, i.e. more persons are classified in the long-spell categories with quite large intervals.

\subsection{Employment and wage models}

In the second phase, we use two models: the one with an indicator of employment now and the other with the log of hourly wage (Mincer earnings function). In both models, we use a set of standard explanatory variables: individual characteristics: age, education, experience and its square, gender and marital status. In both regressions, we add the duration of the unemployment spell. The general form of the models is as follows:

$Y=\alpha_{2 i}+\beta_{20}$ age $_{i}+\beta_{21}$ experience $_{i}+\beta_{22}$ experience_s $_{i}+\beta_{23}$ secondary $_{\text {educ }}+$

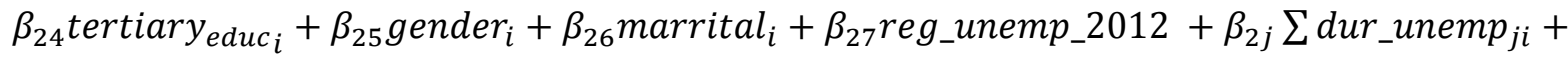
$u_{2 i}$

Whereby: $\mathrm{Y}$ appears in two forms, to reflect the two models we are estimating: i) the probability that a person is employed, $\mathrm{P}(\mathrm{emp})$ takes a value of 1 if the young person $\mathrm{i}$ is in employment now, and zero otherwise; and as lw for the log of the gross hourly wage of person i; the primary education group is the reference group, while the other notations are self-explanatory; Unemployment duration is here represented through four dummy variables, rather than as ordered variable. The four categories of unemployment spell duration are as follows: less than a week or none (the referent category); between a week and a year (short-term spell); between a year and two (medium-term spell); and over two years (long-term spell). We pursue such an approach in order to allow for differential effects on employment and wage prospects of different lengths of the unemployment spell and to gain in better economic interpretation of the key coefficient. $\mathrm{u}_{2 \mathrm{i}}$ is assumed to be well-behaved. 
There are two econometric challenges in estimating (2) and (3): the unobserved wages of those not in employment; and the potential endogeneity of the unemployment spell with respect to both the employment and the wage.

\subsubsection{Missing wages for unemployed}

In our sample, we observe the wages only for those who are in employment5, i.e. in our wage distribution, unemployed youth would not feature. In particular, if selection into employment is nonrandom due to some observable (like education or unobservable factors (like family or political ties), then it makes sense to worry about the way selection may impact our result. One solution to this may be the Heckman (1976; 1979) two-step procedure. However, it has been exposed to some criticism (see, e.g. Petreski et al. 2014). The first line of criticism is related to the exclusion restrictions, i.e. the variables explaining the selection equation, but not the outcome one. In the practical work, the selection equation needs variables which are not included in the outcome equation, i.e. affect the decision to participate in the labor market, but do not affect the wage. The literature includes variety of variables, like the marital status and the number of children, but there is no guarantee that they remain unrelated to wages, albeit statistical tests may suggest so. The second line of criticism is related to the observation of Leung and Yu (1996) who find that the collinearity between the outcome-equation regressors and the inverse Mills ratio may be the main source of high inefficiency of the Heckman estimator. It could be caused either by the exclusion restrictions, which we argued may not be independent of the wage; or by the large share of missing data, which is also the case in our sample (about $86 \%$ of young individuals do not have a wage in the sample).

Our empirical strategy consists of replication of the counterfactual wage distribution that would have prevailed had all young persons in our sample been employed and had the selection into employment been fully random. To devise this counterfactual wage distribution, we use an alternative imputation technique, applied to other type of labor-market phenomena in e.g. Neal (2004) and Olivetti and Petronoglo (2008). The advantage of this technique is that it requires assumption on the position of the imputed wage observation with respect to the median, i.e. avoids the problem of the actual level of the missing wage, which is something required in the matching approach, while also avoiding the Heckman problem with the exclusion restrictions. The identification assumption of this approach is that the assignment of the person below or above the median is based on observable characteristics.

\footnotetext{
${ }^{5}$ Actually, we observe the wage only for $49 \%$ of the total number of employed youth. The reason is that $30 \%$ and $7 \%$ of the sample of employed are unpaid family workers and self-employed, respectively, for which the wage is missing or unobserved. The rest claimed to have received the salary in kind or simply refused to state an amount.
} 
The imputation rule assumes:

$F\left(m, I_{i}=0, X_{i}\right)=\hat{P}_{i}$

Whereby $\mathrm{F}(\mathrm{m})$ is the cumulative distribution function of the low median wage; $\mathrm{I}_{\mathrm{i}}=0$ refers to the case when person I is non-employed and hence his/her wage is non-observed; $X_{i}$ is a vector of observable characteristics; and $\widehat{\mathrm{P}}_{\mathrm{i}}$ is the predicted probability to belong below the median, based on probit estimates.

So, we firstly estimate the probability that an individual has a wage above the median wage, based on observable characteristics: age, experience, education, gender and marital status. On the sample of observed wages, we define $M_{i}=1$ for individuals earning more than the median and $M_{i}=0$ for the others. We estimate a probit model for $\mathrm{M}_{\mathrm{i}}$ with the explanatory variables $\mathrm{X}_{\mathrm{i}}$. Using the probit estimates, we obtain predicted probabilities of having a latent wage above the median, $\widehat{P}_{i}=\Phi\left(\hat{\gamma} X_{i}\right)=\operatorname{Pr}\left(M_{i}=\right.$ $\left.1 \mid X_{\mathrm{i}}\right)$, for the non-employed subset, where $\Phi$ is the cumulative distribution function of the standardized normal distribution and $\hat{\gamma}$ is the estimated parameter vector from the probit regression.

Predicted probabilities $\widehat{\mathrm{P}}_{\mathrm{i}}$ are then used in the second step as sampling weights for the non-employed. In other words, we construct an imputed sample in which the employed feature with their observed wage and the non-employed with a wage above the median with a weight $\widehat{\mathrm{P}}_{\mathrm{i}}$ and a wage below the median with a weight $1-\widehat{\mathrm{P}}_{\mathrm{i}}$. Then, the statistic of interest is the coefficient on unemployment spell duration.

We use a variant of 100 imputations, to be in line with the suggestions of the newer literature (e.g. Graham et al. 2007) which argues that increasing the number of imputations increases the efficiency of the estimations. Overall, the advantage of this approach is that it uses all available information on the characteristics of the non-employed youth and of taking the uncertainty about the reason for the missing wages (Olivetti and Petrongolo, 2008). In other words, unlike in simple deterministic imputation, inference based on repeated imputation considers the additional variability underlying the presence of missing values.

\subsubsection{Endogeneity}

The unemployment duration may suffer endogeneity, mainly stemming from the work of third unobservable factors. Namely, the advantage we obtain with addressing selection due to observables may be plagued by the work of unobservables. For instance, higher ability or motivation may lead to better employment prospects and higher wage and reduce the unemployment duration; if not appropriately modelled, the presence of endogenous regressor may render our estimates of the employment and wage 'scarring' biased (as in, say, Cooper, 2014). We proceed as usual in the literature, by instrumenting the unemployment duration in (2) and (3). We use the regional unemployment rate at the time of exiting education as instrument, similarly as in Gregg (2001), Gregg and Tominey (2005), Schmillen and Umkehrer (2013) and Ghirelli (2015). In our sample, we have a span of 20 years when 
individuals completed school (1993-2012), which multiplied by 8 planning regions in Macedonia produces sufficient variability of the instrumental variable.

This variable should satisfy the two conditions of a good instrument: i) it significantly affects the unemployment spell duration (which is directly testable by observing the results of equation (1) presented in Table 4); and ii) it is not correlated with the error term in the structural equation, i.e. there it is no correlated with the shocks onto employment and wages. The second condition is not directly testable, but as Gregg and Tominey (2005: 499) argue: “... at such a young age, the individuals have little autonomy over their area of residence, thus the personal characteristics of the individuals are removed from the equation.” In other words, local labor-market conditions when the individuals completed school will not directly impact upon later employment prospects except through scarring, hence generating a variation in the early labor-market experience that is uncorrelated with the unobserved factors that may influence both unemployment spell and later labor-market performances. There are two caveats in using the regional unemployment rates at school-end as instrument. First, if individuals, in the meantime (i.e. between the time of observing the local unemployment rate and the time of observing the employment/wage), commit endogenous migration, i.e. move in another region offering more job opportunities, then the effect of the unemployment duration on employment and wage prospect may be underestimated (Ghirelli, 2015). While majority of such migration in Macedonia is expected to have happened intra-regionally (especially at the village-town relation), the wave of migrating from the other larger towns to the capital (inter-regionally), taking place particularly before the crisis of 2007 hit should not be easily disregarded. To prevent potential correlation between the error in the employment/wage equation and the instrument due to this, in equations (2) and (3) we include the local unemployment rate in 2012 (the year of the survey). So, after controlling for later local unemployment conditions (2012), local unemployment at the time the person finished schooling is deemed an exogenous instrument capturing some of the variation in early unemployment experience. The argument is that these local labor market conditions at the time of school-end will not directly influence later unemployment experience, conditional on local area unemployment in 2012, except through the scarring effects of the youths' early unemployment.

Second, local labor-market conditions at school-end may not be related to person's employment and wage outcomes later, but may be correlated with some characteristics of the parents. If some parental unobserved characteristics, Gregg (2001: 637) argues, affect child's later labor-market chances, then this inhibits the power of our instrument. However, "it does at least take the unobserved heterogeneity back a generation.” While no particular steps could be undertaken to improve the instrument for the second caveat, one should at least bear it in mind when interpreting results. 
To make use of the proposed instrument, in equations (2) and (3) instead of the duration of unemployment we add the predicted duration of unemployment6 obtained from (1)7:

$$
\begin{aligned}
& Y=\alpha_{3 i}+\beta_{30} \text { age }_{i}+\beta_{31} \text { experience }_{i}+\beta_{32} \text { experience_s }_{i}+\beta_{33} \text { secondary }_{\text {educ }_{i}}+ \\
& \beta_{34} \text { tertiary }_{\text {educ }_{i}}+\beta_{35} \text { gender }_{i}+\beta_{36} \text { marrital }_{i}+\beta_{37} \text { reg_unemp_L }_{-} 2012+\theta_{j} \sum \text { dur_unemp }_{i j}+ \\
& u_{4 i}
\end{aligned}
$$

Whereby dur_unemp $p_{1}$ stands for the predicted duration derived from equation (1) and is again represented through four categories. $\theta_{\mathrm{j}}$ reveals how the unemployment spell of particular duration purged from unobservable factors affects the employment/wage prospects, fully freed of selection bias. The variables' definitions are summarized in Table 14 in Appendix 1.

\section{Results and discussion}

\subsection{Results on the unemployment spell}

In order to empirically explore for the determinants of the unemployment spell, we first present graphs from the Kaplan-Meier non-parametric method, providing the survival probabilities as a function of time. Figure 7 presents the survivor function for all persons, and then for those still unemployed (censored) vis-à-vis those already employed; and for males versus females. In general, it shows the proportion of people who did not experience the event, i.e., who are still in the original state, which in our case, is unemployment. The upper graph documents the well-known fact for Macedonian youth unemployment: it has long-term characteristics as more than $50 \%$ of persons search for job for more than a year, while nearly $40 \%$ for more than two years. Lower left graph suggests that those who are still unemployed have apparently longer unemployment spells than those who found employment,

\footnotetext{
${ }^{6}$ In our case, we are instrumenting three endogenous dummies with one instrument, the prime line of justification being that the three endogenous dummies are reflecting one single phenomenon - the unemployment spell. Since this may be still objected, Appendix 2 presents the results of another estimator utilizing internally generated instruments. In addition, we rely on the repeated imputation technique in the estimation of the wage equation. Hence, ivreg (or similar command) in Stata is technically not feasible. Hence, we conduct IV correction manually, as suggested in Wooldridge (2002). We are limited to provide the usual under- and weak-identification statistics due to the specific methodological construct we use here. However, we do some approximations, which are presented in Appendix 2.

${ }^{7}$ More precisely, we use the predicted unemployment spell duration from the equation where it is regressed on the individual characteristics only, plus the regional unemployment rate when person ended school. The former are the variables entering the wage regression (included instruments), while the latter is the exclusion restriction (excluded instrument).
} 
suggesting that the two groups may have different characteristics and the consideration of censoring is needed. The log-rank test produces a probability value of 0.000 , rejecting the null that the two groups have equal survivor functions. On the other hand, the visual difference of the survival functions between males and females cannot be established (lower right graph), as unemployment-spell probabilities seem similar. However, the log-rank test produces a value of 0.0889 , hence failing to provide support to the visual conclusion at the $10 \%$. Therefore, a separate consideration of the survival functions of young males and females may be worth examining further.

Figure 7 - Kaplan-Meier Survival Estimates
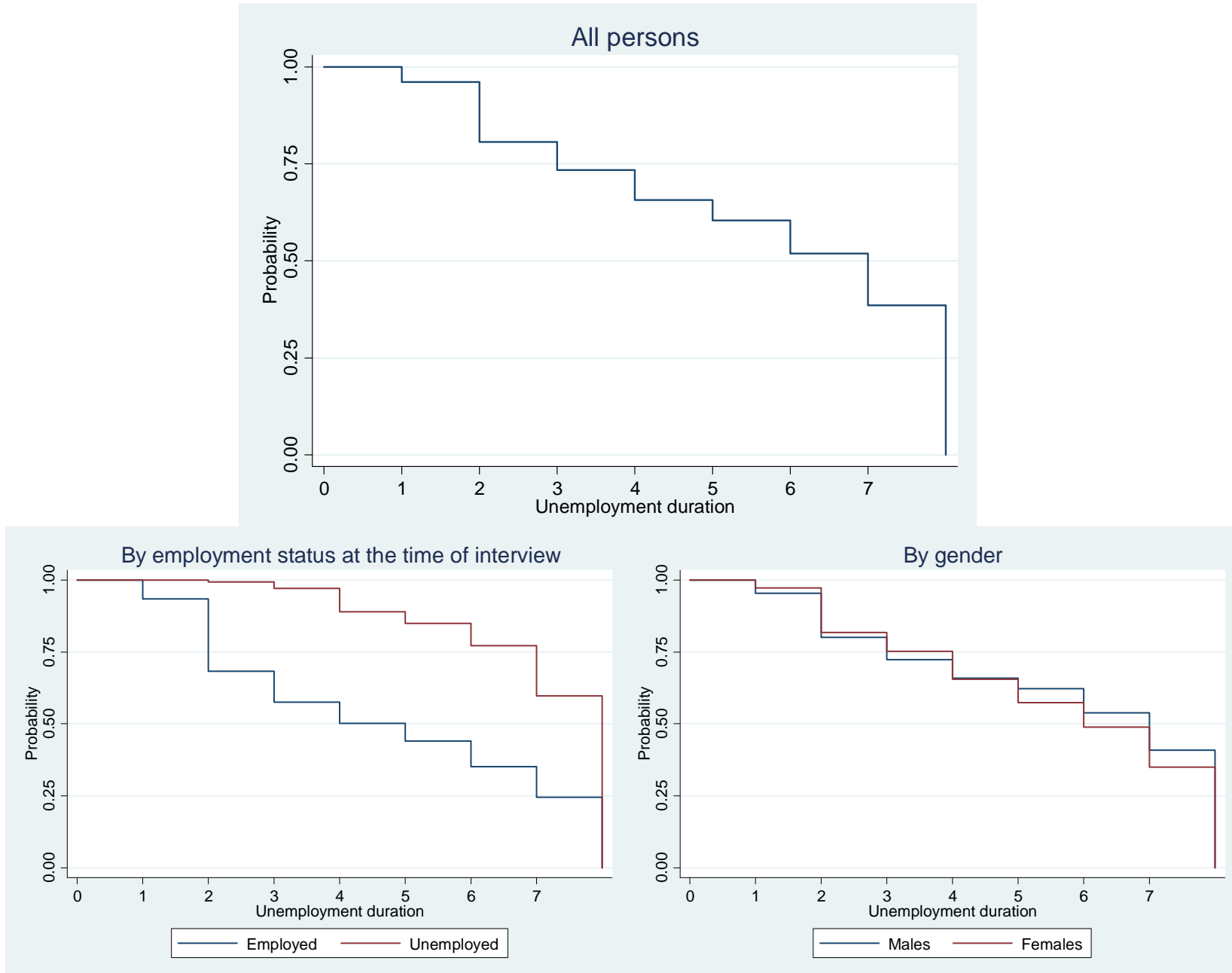

Source: Authors' estimates. 
Table 4 provides the estimates of equation (1) - the unemployment spell model: the table provides the hazard coefficients. Columns (1)-(4) present the results for the entire model, adding variables group by group. Columns (5) and (6) present the results by gender. We will be interpreting the results in column (4) being the most integral in terms of the included variables. It takes longer to older persons to find employment: an additional year reduces employment chances by $0.3 \%$, on average. Experience, education, gender and marital status, along our observations in Table 3 are insignificant for the unemployment spell.

When it comes to socio-economic characteristics of the household, only father's education and household's financial condition matter. Young person's chances to exit unemployment are lower by about $1.5 \%$ and $3.7 \%$ when their father possesses secondary or tertiary education, respectively, compared to person's father with primary education. This result may be related to the fact that children do not separate from parents until late age or never, suggesting that the more the parents earn, the more comfortable children feel in searching for the dream job. The worse the financial situation of the household is, likely corresponding to the scarcity of family ties and network, the longer it takes to exit unemployment.

In the 'working preferences and attitudes' variables, three are found significant for the unemployment spell. The fact that the young person pursued an internship while studying increased the probability that he/she exits unemployment by $1.7 \%$. On the other hand, aiming at career while studying reduced the chances for exiting unemployment by $6.4 \%$ which may be odd, but may be explained by the possibly high expectations that these persons inflict onto themselves. The reservation wage is also significant: a percent higher wage below which a person would not accept a job increases the chance to exit unemployment by about $1.3 \%$. This result may be peculiar at first sight, but may signify that self-esteem and self-confidence (reflected in higher reservation wage) may actually play an important role in finding a job. It seems the role of the reservation wage for the unemployment duration is similar for males and females.

Finally, towards the bottom of the table, the regional unemployment rate at the time the individual finished school is negative and statistically significant, suggesting that regions with scarcer employment opportunities at graduation negatively impinged on subsequent employment outcomes. This suggests that one of the two conditions for a good instrument is satisfied. 
Table 4 - Baseline results - Unemployment spell (marginal probabilities)

\begin{tabular}{|c|c|c|c|c|c|c|}
\hline \multicolumn{7}{|c|}{ Dependent variable: Event occurrence (0: Event did not happen; 1: Event happened) } \\
\hline & \multicolumn{4}{|c|}{ Model (1) } & \multicolumn{2}{|c|}{ Model (1) by gender } \\
\hline & $\begin{array}{l}\text { Only individual } \\
\text { characteristics }\end{array}$ & $\begin{array}{c}\text { Individual } \\
\text { char. And } \\
\text { regional } \\
\text { unemp. }\end{array}$ & $\begin{array}{l}\text { Individual and } \\
\text { socio-econ. } \\
\text { characteristics }\end{array}$ & $\begin{array}{l}\text { Entire } \\
\text { model }\end{array}$ & Males & Females \\
\hline & (1) & $(2)$ & (3) & (4) & (5) & (6) \\
\hline \multicolumn{7}{|c|}{ Individual characteristics } \\
\hline \multirow[t]{2}{*}{ Age (in years) } & 0.001 & 0.001 & 0.000 & $-0.003 * *$ & $-0.003^{*}$ & $-0.005^{*}$ \\
\hline & $(0.001)$ & $(0.002)$ & $(0.002)$ & $(0.002)$ & $(0.002)$ & $(0.003)$ \\
\hline \multirow[t]{2}{*}{ Experience (in years) } & $0.009 * * *$ & $0.007 * * *$ & $0.007 * * *$ & 0.003 & 0.004 & 0.005 \\
\hline & $(0.002)$ & $(0.002)$ & $(0.002)$ & $(0.003)$ & $(0.003)$ & $(0.006)$ \\
\hline \multirow[t]{2}{*}{ Gender (1=female) } & 0.008 & 0.011 & 0.011 & 0.012 & & \\
\hline & $(0.009)$ & $(0.009)$ & $(0.009)$ & $(0.008)$ & & \\
\hline \multirow[t]{2}{*}{ Secondary education } & 0.008 & 0.007 & -0.005 & -0.014 & -0.012 & -0.019 \\
\hline & $(0.011)$ & $(0.011)$ & $(0.012)$ & $(0.012)$ & $(0.014)$ & $(0.019)$ \\
\hline \multirow[t]{2}{*}{ Tertiary education } & $0.044 * * *$ & $0.043^{* * *}$ & 0.02 & 0.014 & 0.026 & 0.005 \\
\hline & $(0.015)$ & $(0.014)$ & $(0.016)$ & $(0.016)$ & $(0.019)$ & $(0.027)$ \\
\hline \multirow{2}{*}{$\begin{array}{l}\text { Marital status } \\
(1=\text { married })\end{array}$} & -0.001 & -0.002 & 0.000 & -0.014 & -0.016 & -0.004 \\
\hline & $(0.010)$ & $(0.010)$ & $(0.011)$ & $(0.010)$ & $(0.012)$ & $(0.018)$ \\
\hline \multicolumn{7}{|c|}{ Socio-economic characteristics } \\
\hline \multirow{2}{*}{$\begin{array}{l}\text { Number of children in the } \\
\text { household }\end{array}$} & & & 0.0000 & 0.004 & 0.005 & 0.004 \\
\hline & & & $(0.006)$ & $(0.006)$ & $(0.007)$ & $(0.009)$ \\
\hline \multirow{2}{*}{$\begin{array}{l}\text { Secondary education of } \\
\text { father }\end{array}$} & & & -0.007 & $-0.015^{*}$ & $-0.023 * *$ & -0.002 \\
\hline & & & $(0.011)$ & $(0.009)$ & $(0.011)$ & $(0.016)$ \\
\hline \multirow{2}{*}{$\begin{array}{l}\text { Tertiary education of } \\
\text { father }\end{array}$} & & & $-0.042^{* *}$ & $-0.037 * *$ & -0.03 & -0.03 \\
\hline & & & $(0.017)$ & $(0.016)$ & $(0.023)$ & $(0.025)$ \\
\hline \multirow{2}{*}{$\begin{array}{l}\text { Secondary education of } \\
\text { mother }\end{array}$} & & & $0.029 * * *$ & 0.012 & $0.019 *$ & -0.003 \\
\hline & & & $(0.010)$ & $(0.009)$ & $(0.010)$ & $(0.017)$ \\
\hline \multirow{2}{*}{$\begin{array}{l}\text { Tertiary education of } \\
\text { mother }\end{array}$} & & & $0.041 * * *$ & 0.014 & 0.006 & 0.02 \\
\hline & & & $(0.015)$ & $(0.014)$ & $(0.018)$ & $(0.023)$ \\
\hline \multirow{2}{*}{$\begin{array}{l}\text { Financial condition of } \\
\text { household }\end{array}$} & & & $-0.017 * * *$ & $-0.013^{* * *}$ & $-0.011 * * *$ & $-0.017 * * *$ \\
\hline & & & $(0.003)$ & $(0.003)$ & $(0.003)$ & $(0.006)$ \\
\hline \multicolumn{7}{|c|}{ Working preferences and attitudes } \\
\hline \multirow{2}{*}{$\begin{array}{l}\text { At least one internship } \\
\text { while studying (1=yes) }\end{array}$} & & & & $0.017^{*}$ & 0.010 & 0.02 \\
\hline & & & & $(0.009)$ & $(0.011)$ & $(0.016)$ \\
\hline \multirow[t]{2}{*}{ Goal today $(1$ = career $)$} & & & & 0.008 & 0.000 & 0.024 \\
\hline & & & & $(0.008)$ & $(0.008)$ & $(0.017)$ \\
\hline \multirow{2}{*}{$\begin{array}{l}\text { Goal while studying (1 = } \\
\text { career) }\end{array}$} & & & & $-0.064 * * *$ & $-0.057 * * *$ & $-0.103 * *$ \\
\hline & & & & $(0.019)$ & $(0.018)$ & $(0.047)$ \\
\hline \multirow[t]{2}{*}{ Log reservation wage } & & & & $0.013 * * *$ & $0.014 * * *$ & $0.014 * * *$ \\
\hline & & & & $(0.001)$ & $(0.001)$ & $(0.001)$ \\
\hline \multirow[t]{2}{*}{ Job search intensity } & & & & -0.001 & 0.000 & -0.003 \\
\hline & & & & $(0.001)$ & $(0.001)$ & $(0.002)$ \\
\hline & Regio & al unemployı & nt rate at school & & & \\
\hline Regional unemployment & & $-0.001 * * *$ & $-0.001 * * *$ & $-0.001 * *$ & 0.000 & $-0.002 * * *$ \\
\hline rate at school end & & $(0.000)$ & $(0.000)$ & $(0.000)$ & $(0.000)$ & $(0.001)$ \\
\hline Number of individuals & 1,044 & 1,044 & 1,044 & 1,044 & 655 & 389 \\
\hline Total observations & 6,363 & 6,325 & 6,325 & 6,325 & 4,009 & 2,316 \\
\hline
\end{tabular}


Table 5 gives the survival marginal probabilities, i.e. the chances that the unemployment spell lasts for a certain period of time, as defined by the intervals of our dependent variable. The probability hovers around $4-7 \%$ for the duration groups of up to 6 months of unemployment; increases to about $10 \%$ for unemployment duration of 6 to 12 months; jumps to $14 \%$ for unemployment duration above one year; and soars at $40 \%$ for duration longer than two years. This is a peculiarity of the Macedonian labor market, suggesting that the longer a young person is unemployed, the higher the probability that he/she will remain unemployed, and coincides with the fact that the largest share of young persons belongs to the group of long-term unemployed (Section 4).

Table 5 - Survival marginal probabilities - Unemployment spell

\begin{tabular}{|c|c|c|c|c|}
\hline & \multirow[t]{2}{*}{ All } & \multicolumn{3}{|c|}{ By gender } \\
\hline & & Males & Females & $\begin{array}{l}\text { Statistical } \\
\text { difference }\end{array}$ \\
\hline Unemployment spell duration & (1) & (2) & (3) & $(4)$ \\
\hline \multirow[t]{2}{*}{ No unemployment spell } & $0.0199 * * *$ & $0.0143^{* * *}$ & $0.0277^{*}$ & Yes \\
\hline & $(0.007)$ & $(0.005)$ & $(0.016)$ & \\
\hline \multirow[t]{2}{*}{ Less than a week } & $0.0810^{* * *}$ & $0.0744 * * *$ & $0.0893^{* * *}$ & No \\
\hline & $(0.009)$ & $(0.011)$ & $(0.015)$ & \\
\hline \multirow[t]{2}{*}{ Week to month } & $0.0652 * * *$ & $0.0739 * * *$ & $0.0512 * * *$ & Yes \\
\hline & $(0.009)$ & $(0.012)$ & $(0.012)$ & \\
\hline \multirow[t]{2}{*}{ 1-3 months } & $0.0536^{* * *}$ & $0.0414 * * *$ & $0.0725^{* * *}$ & Yes \\
\hline & $(0.009)$ & $(0.010)$ & $(0.015)$ & \\
\hline \multirow[t]{2}{*}{ 3-6 months } & $0.0484 * * *$ & $0.0305^{* * *}$ & $0.0780 * * *$ & Yes \\
\hline & $(0.009)$ & $(0.009)$ & $(0.017)$ & \\
\hline \multirow[t]{2}{*}{6 months to a year } & $0.0978^{* * *}$ & $0.101^{* * *}$ & $0.0930 * * *$ & No \\
\hline & $(0.014)$ & $(0.016)$ & $(0.027)$ & \\
\hline \multirow[t]{2}{*}{ 1-2 years } & $0.139 * * *$ & $0.143^{* * *}$ & $0.137 * * *$ & No \\
\hline & $(0.016)$ & $(0.020)$ & $(0.026)$ & \\
\hline \multirow[t]{2}{*}{2 and more years } & $0.412 * * *$ & $0.405 * * *$ & $0.430 * * *$ & No \\
\hline & $(0.021)$ & $(0.025)$ & $(0.035)$ & \\
\hline Number of individuals & 1,044 & 655 & 389 & \\
\hline Total number of observations & 6,363 & 4,033 & 2,330 & \\
\hline \multicolumn{5}{|c|}{$\begin{array}{l}\text { Source: Authors' estimations. } \\
\text { Notes: *, ** and *** denote statistical significance at the } 10,5 \text { and } 1 \% \text { level, } \\
\text { respectively. Results are robust to heteroskedasticity and clustered at the individual } \\
\text { level. Weights provided with the survey have been used to account for survey’s } \\
\text { structure. }\end{array}$} \\
\hline
\end{tabular}

Differences between young males and females do exist for the duration of unemployment between week and six months, whereby females have lower probability to stay unemployed for the shorter duration groups, while the regularity reverses for the longer duration groups. Gender differences exist also for those who did not experience an unemployment spell, where males are in a more favorable position in this group. 


\subsection{Results of the employment and wage analysis}

In this section we empirically analyze the relationship between previous unemployment episodes and subsequent employment and wage performance. The results of the employment model are given in Table 6. We first report the probit results (without instrumentation, column 1); then the endogeneitycorrected results (column 2). The last two columns disaggregate by gender.

Results suggest that unemployment duration is significant for the future employment, suggesting a presence of employment scar among Macedonian youth. Individual with a short-term spell has lower probability of $28.4 \%$ to get employed than person with a spell of less than a week (including no spell at all). The scar for individuals with medium-term and long-term spells are, respectively, $42.6 \%$ and $61.8 \%$. Hence, the scarring effect grows with the duration of the unemployment spell, i.e. the latter significantly undermines employment opportunities of youth, especially in the long run. When the employment scar is observed by gender, it appears stronger for the short-to-medium-term for females, and vice-versa for males. Some explanation for these gender differences may be sought in the different expectations between genders in finding a job, employers considering the childbearing period for women and so on.

Almost all of the other explanatory variables are significant. Additional year of age increases the employment opportunity by $5.4 \%$, while experience has a negative effect: additional year of experience reduces employment opportunities by 12\%, but the effect turns positive after about 5.2 years of experience. The negative role of experience is especially pronounced for females. Only secondary education brings employment payoff, estimated at $15 \%$ compared to primary education, but it is significant for males only. Finally, married individuals have higher employment opportunities by $11 \%$ than non-married, but the effect is prevalent only among females. Regional labor-market conditions do not significantly affect employment opportunities for youth (despite the sign is correctly negative). 
Table 6 - Baseline results - Employment function (marginal effects)

\begin{tabular}{|c|c|c|c|c|c|}
\hline \multicolumn{6}{|c|}{ Dependent variable: 1 = Person is employed now } \\
\hline & & \multirow[t]{3}{*}{ Probit } & \multicolumn{3}{|c|}{ Instrumental-variable probit } \\
\hline & & & \multirow[t]{2}{*}{ All } & \multicolumn{2}{|c|}{ By gender } \\
\hline & & & & Males & Females \\
\hline & & (1) & (2) & (3) & (4) \\
\hline \multirow{2}{*}{\multicolumn{2}{|c|}{ Age (in years) }} & $0.0516 * * *$ & $0.0535^{* * *}$ & $0.0620 * * *$ & $0.0464 * * *$ \\
\hline & & $(0.008)$ & (0.008) & $(0.011)$ & $(0.013)$ \\
\hline \multirow{2}{*}{\multicolumn{2}{|c|}{ Experience (in years) }} & $-0.107 * * *$ & $-0.120 * * *$ & $-0.0928 * *$ & $-0.241 * *$ \\
\hline & & $(0.036)$ & $(0.036)$ & $(0.042)$ & $(0.095)$ \\
\hline \multirow{2}{*}{\multicolumn{2}{|c|}{ Experience squared }} & $0.0105^{* *}$ & $0.0116 * *$ & 0.00779 & $0.0326 *$ \\
\hline & & $(0.005)$ & $(0.005)$ & $(0.006)$ & $(0.017)$ \\
\hline \multirow{2}{*}{\multicolumn{2}{|c|}{ Gender (1=female) }} & -0.0612 & -0.0669 & & \\
\hline & & $(0.043)$ & $(0.043)$ & & \\
\hline \multirow{2}{*}{\multicolumn{2}{|c|}{ Secondary education }} & $0.182 * * *$ & $0.150 * * *$ & $0.187 * * *$ & 0.0579 \\
\hline & & $(0.055)$ & $(0.054)$ & $(0.065)$ & $(0.097)$ \\
\hline \multirow{2}{*}{\multicolumn{2}{|c|}{ Tertiary education }} & 0.0259 & -0.0242 & -0.118 & -0.00904 \\
\hline & & $(0.073)$ & $(0.075)$ & $(0.096)$ & $(0.122)$ \\
\hline \multirow{2}{*}{\multicolumn{2}{|c|}{$\begin{array}{l}\text { Marital status } \\
\text { (1=married) }\end{array}$}} & $0.108 * *$ & $0.110 * *$ & 0.0278 & $0.187 * * *$ \\
\hline & & $(0.047)$ & $(0.049)$ & $(0.069)$ & $(0.070)$ \\
\hline \multirow{2}{*}{\multicolumn{2}{|c|}{$\begin{array}{l}\text { Regional unemployment } \\
\text { rate in } 2012\end{array}$}} & -0.00015 & -0.00028 & -0.00117 & 0.00193 \\
\hline & & $(0.002)$ & $(0.002)$ & $(0.002)$ & $(0.002)$ \\
\hline \multirow{6}{*}{ 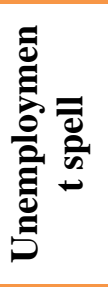 } & \multirow[t]{2}{*}{ Week to a year } & $-0.654 * * *$ & $-0.284 * * *$ & $-0.221 * *$ & $-0.322 * * *$ \\
\hline & & $(0.094)$ & $(0.068)$ & $(0.096)$ & $(0.101)$ \\
\hline & \multirow[t]{2}{*}{ A year to two } & $-0.711 * * *$ & $-0.426 * * *$ & $-0.429 * * *$ & $-0.436 * * *$ \\
\hline & & $(0.051)$ & $(0.046)$ & $(0.060)$ & $(0.071)$ \\
\hline & \multirow{2}{*}{$\begin{array}{l}\text { More than two } \\
\text { years }\end{array}$} & $-0.884 * * *$ & $-0.618 * * *$ & $-0.658 * * *$ & $-0.578 * * *$ \\
\hline & & $(0.046)$ & $(0.038)$ & $(0.047)$ & $(0.065)$ \\
\hline \multicolumn{2}{|c|}{ Observations } & 1,044 & 1,044 & 655 & 389 \\
\hline \multicolumn{6}{|c|}{$\begin{array}{l}\text { Source: Authors' estimations. } \\
\text { Notes: *, ** and *** denote statistical significance at the } 10,5 \text { and } 1 \% \text { level, } \\
\text { respectively. Results are robust to heteroskedasticity. Weights provided along the } \\
\text { survey used In the analysis. Regional unemployment rate in the year when the } \\
\text { individual finished school is used as instrument for the unemplovment spell. }\end{array}$} \\
\hline
\end{tabular}

Table 7 presents the employment scar for different subgroupings. Namely, the gender-split groups are further split by age, experience and education. It is generally expected that the employment scar may differ based on whether the person has previous experience or not, the age, and based on his/her educational attainment. In general, the employment scar is present among all subgroupings, except the short-term scar of males. Some specific conclusions are as follows: i) younger males face stronger scar than older males, while the opposite holds for females; ii) both experienced males and females exhibit weaker scar than the non-experienced counterparts; and iii) females face stronger scars than males across education groups, while within-gender differences across education are neither large nor with a specific pattern. 
Table 7 - Baseline results - Employment function for subgroups (marginal effects)

\begin{tabular}{|c|c|c|c|c|c|c|c|c|}
\hline \multicolumn{9}{|c|}{ Dependent variable: 1 = Person is employed now } \\
\hline & & \multicolumn{2}{|c|}{ Age } & \multicolumn{2}{|c|}{ Experience } & \multicolumn{3}{|c|}{ Education } \\
\hline & & Below 25 & Above 25 & Without & With & Primary & $\begin{array}{c}\text { Secondar } \\
\mathbf{y}\end{array}$ & Tertiary \\
\hline & & (1) & $(2)$ & (3) & (4) & (5) & (6) & (7) \\
\hline & & & & & Males & & & \\
\hline \multirow{6}{*}{ 竞突 } & \multirow[t]{2}{*}{ Week to a year } & -0.179 & -0.211 & $-0.261 * *$ & -0.212 & -0.0778 & -0.197 & $-0.397 * *$ \\
\hline & & $(0.113)$ & $(0.147)$ & $(0.110)$ & $(0.165)$ & $(0.289)$ & $(0.121)$ & $(0.155)$ \\
\hline & \multirow[t]{2}{*}{ A year to two } & $-0.493 * * *$ & $-0.277 * *$ & $-0.489 * * *$ & $-0.264^{*}$ & $-0.444 * * *$ & $-0.456 * * *$ & $-0.331 * *$ \\
\hline & & $(0.055)$ & $(0.128)$ & $(0.060)$ & $(0.142)$ & $(0.106)$ & $(0.074)$ & $(0.160)$ \\
\hline & \multirow{2}{*}{ More than two years } & $-0.712 * * *$ & $-0.574 * * *$ & $-0.729 * * *$ & $-0.536 * * *$ & $-0.777 * * *$ & $-0.627 * * *$ & $-0.677 * * *$ \\
\hline & & $(0.057)$ & $(0.066)$ & $(0.045)$ & $(0.115)$ & $(0.074)$ & $(0.060)$ & $(0.101)$ \\
\hline \multirow{2}{*}{\multicolumn{2}{|c|}{ Number of observations }} & 340 & 315 & 540 & 115 & 129 & 432 & 94 \\
\hline & & \multicolumn{7}{|c|}{ Females } \\
\hline \multirow{6}{*}{ 芵 } & \multirow[t]{2}{*}{ Week to a year } & $-0.324 * * *$ & $-0.333^{* *}$ & $-0.350 * * *$ & $-0.323 * *$ & $-0.366^{*}$ & -0.239 & $-0.459 * * *$ \\
\hline & & $(0.108)$ & $(0.159)$ & $(0.114)$ & $(0.145)$ & $(0.209)$ & $(0.161)$ & $(0.135)$ \\
\hline & \multirow[t]{2}{*}{ A year to two } & $-0.422 * * *$ & $-0.530 * * *$ & $-0.461^{* * *}$ & $-0.512 * * *$ & $-0.466^{* * *}$ & $-0.474 * * *$ & $-0.364^{* *}$ \\
\hline & & $(0.076)$ & $(0.111)$ & $(0.078)$ & $(0.110)$ & $(0.084)$ & $(0.085)$ & $(0.144)$ \\
\hline & \multirow[t]{2}{*}{ More than two years } & $-0.564 * * *$ & $-0.683^{* * *}$ & $-0.692 * * *$ & $-0.399 * *$ & $-0.741 * * *$ & $-0.542 * * *$ & $-0.668 * * *$ \\
\hline & & $(0.081)$ & $(0.077)$ & $(0.062)$ & $(0.158)$ & $(0.108)$ & $(0.081)$ & $(0.132)$ \\
\hline \multicolumn{2}{|c|}{ Number of observations } & 191 & 198 & 317 & 72 & 67 & 206 & 116 \\
\hline \multicolumn{9}{|c|}{$\begin{array}{l}\text { Source: Authors' estimations. } \\
\text { Notes: *, ** and *** denote statistical significance at the } 10,5 \text { and } 1 \% \text { level, respectively. Results are robust to } \\
\text { heteroskedasticity. Weights provided along the survey used In the analysis. The coefficients on the other explanatory variables } \\
\text { not provided to save space, but available on request. Regional unemployment rate in the year when the individual finished school } \\
\text { is used as instrument for the unemployment spell. }\end{array}$} \\
\hline
\end{tabular}

We now turn to discussing the estimates of the model aimed to capture how unemployment spell duration affects wage prospects. The results are given in Table 8. Column (1) presents the results with an OLS, hence without having considered the presence of the selection bias or the work of unobservables. The rest of the columns are based on the repeated imputations technique, hence addressing the selection problem. In addition, column (3) addresses the potential endogeneity of the unemployment duration, by employing an instrumental variable discussed in Section 5.28. Columns (4) and (5) do the same by gender.

Results are quite appealing. They robustly suggest that the unemployment spell does not have a role to play for the wage, i.e. there is no wage 'scarring' effect among youth in Macedonia. The finding is not altered by the consideration of the potential endogeneity of the unemployment duration, nor differs among genders. This result is though in line with some previous studies which do not find the presence of employment and/or wage scar in high unemployment regions (the case of Italy, in Lupi and Ordine, 2002) or in high unemployment countries (the case of Bosnia, in Fares and Tiongson, 2007) (see Section 2).

\footnotetext{
${ }^{8}$ Similarly, we are limited to provide the usual identification statistics due to the specific methodological construct we use here. However, we do some approximations, which are presented in Appendix 2.
} 
With regard to the other explanatory variables, age, tertiary education and marital status of youth are significant for the wage. Additional year of age brings about 3.6\% higher salary, on average. However, age is more valuable for females' wages. Only tertiary education provides fairly large pay off, as these individuals have $22 \%$ higher wage than those with primary education only. This result is significant for males only. Married individuals have nearly $20 \%$ lower wage than singles, which may be though driven by the labor-market status of the spouse.

Table 8 - Baseline results - Mincer function

\begin{tabular}{|c|c|c|c|c|c|c|}
\hline \multicolumn{7}{|c|}{ Dependent variable: Log of the gross hourly wage } \\
\hline & & \multirow{3}{*}{ OLS } & \multicolumn{4}{|c|}{ Imputation } \\
\hline & & & \multicolumn{2}{|c|}{ All } & \multicolumn{2}{|c|}{$\begin{array}{c}\text { By gender } \\
\text { (endogeneity considered) }\end{array}$} \\
\hline & & & $\begin{array}{l}\text { Endogeneity } \\
\text { ignored }\end{array}$ & $\begin{array}{c}\text { Endogeneity } \\
\text { considered }\end{array}$ & Males & Females \\
\hline & & (1) & $(2)$ & (3) & (4) & (5) \\
\hline \multirow{2}{*}{\multicolumn{2}{|c|}{ Age (in years) }} & $0.0365 * * *$ & $0.0365 * * *$ & $0.0357 * * *$ & $0.0290 * *$ & $0.0415^{*}$ \\
\hline & & $(0.012)$ & $(0.014)$ & $(0.013)$ & $(0.012)$ & $(0.021)$ \\
\hline \multirow{2}{*}{\multicolumn{2}{|c|}{ Experience (in years) }} & 0.0153 & 0.0064 & 0.0107 & 0.0201 & -0.0941 \\
\hline & & $(0.051)$ & $(0.045)$ & $(0.044)$ & $(0.048)$ & $(0.109)$ \\
\hline \multirow{2}{*}{\multicolumn{2}{|c|}{ Experience squared }} & -0.00041 & -0.0022 & -0.00311 & -0.0032 & 0.0172 \\
\hline & & $(0.008)$ & $(0.005)$ & $(0.005)$ & $(0.005)$ & $(0.018)$ \\
\hline \multirow{2}{*}{\multicolumn{2}{|c|}{ Gender ( $1=$ female) }} & -0.0473 & 0.0403 & 0.0434 & & \\
\hline & & $(0.058)$ & $(0.062)$ & $(0.063)$ & & \\
\hline \multirow{2}{*}{\multicolumn{2}{|c|}{ Secondary education }} & $-0.221 * *$ & -0.00619 & -0.00668 & -0.0141 & -0.0163 \\
\hline & & $(0.088)$ & $(0.067)$ & $(0.067)$ & $(0.082)$ & $(0.106)$ \\
\hline \multirow{2}{*}{\multicolumn{2}{|c|}{ Tertiary education }} & 0.14 & $0.228 * *$ & $0.222 * *$ & $0.266 * *$ & 0.183 \\
\hline & & $(0.091)$ & $(0.100)$ & $(0.100)$ & $(0.118)$ & $(0.151)$ \\
\hline \multirow{2}{*}{\multicolumn{2}{|c|}{$\begin{array}{l}\text { Marital status } \\
\text { (1=married) }\end{array}$}} & $-0.243^{* * *}$ & $-0.200 * * *$ & $-0.199 * * *$ & $-0.176^{* *}$ & $-0.190^{*}$ \\
\hline & & $(0.065)$ & $(0.074)$ & $(0.073)$ & $(0.081)$ & $(0.106)$ \\
\hline \multirow{2}{*}{\multicolumn{2}{|c|}{$\begin{array}{l}\text { Regional unemployment } \\
\text { rate in } 2012\end{array}$}} & $\begin{array}{l}- \\
0.00610 * *\end{array}$ & -0.0031 & -0.00295 & -0.00166 & -0.00482 \\
\hline & & $(0.003)$ & $(0.002)$ & $(0.002)$ & $(0.003)$ & $(0.004)$ \\
\hline \multirow{6}{*}{ 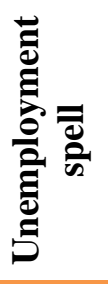 } & \multirow[t]{2}{*}{ Week to a year } & 0.0567 & 0.0275 & 0.124 & -0.0611 & 0.388 \\
\hline & & $(0.078)$ & $(0.095)$ & $(0.161)$ & $(0.096)$ & $(0.309)$ \\
\hline & \multirow[t]{2}{*}{ A year to two } & 0.134 & -0.00914 & -0.00146 & 0.00491 & -0.03 \\
\hline & & $(0.100)$ & $(0.100)$ & $(0.079)$ & $(0.098)$ & $(0.122)$ \\
\hline & \multirow{2}{*}{$\begin{array}{l}\text { More than two } \\
\text { years }\end{array}$} & 0.104 & -0.0471 & -0.0383 & -0.0108 & -0.0995 \\
\hline & & $(0.097)$ & $(0.090)$ & $(0.066)$ & $(0.081)$ & $(0.109)$ \\
\hline \multirow{2}{*}{\multicolumn{2}{|c|}{ Constant }} & $3.804 * * *$ & $3.632 * * *$ & $3.638 * * *$ & $3.751^{* * *}$ & $3.628 * * *$ \\
\hline & & $(0.322)$ & $(0.299)$ & $(0.283)$ & $(0.298)$ & $(0.409)$ \\
\hline \multicolumn{2}{|c|}{ Observations } & 352 & 1,044 & 1,044 & 655 & 389 \\
\hline \multicolumn{7}{|c|}{$\begin{array}{l}\text { Source: Authors' estimations. } \\
\text { Notes: *, ** and }{ }^{* * *} \text { denote statistical significance at the } 10,5 \text { and } 1 \% \text { level, respectively. Results } \\
\text { are robust to heteroskedasticity. Weights provided along the survey used In the analysis. Regional } \\
\text { unemployment rate in the year when the individual finished school is used as instrument for the } \\
\text { unemployment spell. }\end{array}$} \\
\hline
\end{tabular}


In Table 9 we present the wage scarring effect for the different subgroupings of the two genders. Results unanimously suggest no wage scarring effect among sub-groups.

Table 9 - Baseline results - Mincer function for subgroups

\begin{tabular}{|c|c|c|c|c|c|c|c|c|}
\hline \multicolumn{9}{|c|}{ Dependent variable: Log of the gross hourly wage } \\
\hline & & \multicolumn{2}{|c|}{ Age } & \multicolumn{2}{|c|}{ Experience } & \multicolumn{3}{|c|}{ Education } \\
\hline & & Below 25 & $\begin{array}{c}\text { Above } \\
25\end{array}$ & Without & With & Primary & $\begin{array}{l}\text { Seconda } \\
\text { ry }\end{array}$ & Tertiary \\
\hline & & (1) & (2) & (3) & (4) & (5) & (6) & (7) \\
\hline & & \multicolumn{7}{|c|}{ Males } \\
\hline \multirow{6}{*}{ 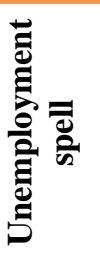 } & \multirow[t]{2}{*}{ Week to a year } & 0.004 & -0.042 & 0.0336 & -0.0992 & 0.126 & -0.0514 & 0.00403 \\
\hline & & $(0.130)$ & $(0.151)$ & $(0.106)$ & $(0.190)$ & $(0.216)$ & $(0.114)$ & $(0.199)$ \\
\hline & \multirow[t]{2}{*}{ A year to two } & -0.028 & -0.012 & -0.00702 & 0.0398 & 0.00348 & -0.0367 & 0.155 \\
\hline & & $(0.123)$ & $(0.155)$ & $(0.102)$ & $(0.209)$ & $(0.220)$ & $(0.123)$ & $(0.201)$ \\
\hline & \multirow{2}{*}{$\begin{array}{l}\text { More than two } \\
\text { years }\end{array}$} & -0.013 & -0.022 & -0.0392 & 0.16 & -0.0334 & -0.0209 & 0.00535 \\
\hline & & $(0.121)$ & $(0.112)$ & $(0.090)$ & $(0.217)$ & $(0.171)$ & $(0.101)$ & $(0.197)$ \\
\hline \multirow{2}{*}{\multicolumn{2}{|c|}{ Number of observations }} & 356 & 323 & 564 & 115 & 145 & 440 & 94 \\
\hline & & \multicolumn{7}{|c|}{ Females } \\
\hline \multirow{6}{*}{ 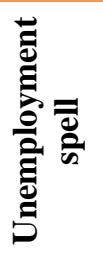 } & \multirow[t]{2}{*}{ Week to a year } & 0.00451 & 0.418 & 0.469 & -0.0381 & -0.0624 & 0.629 & -0.0795 \\
\hline & & $(0.219)$ & $(0.322)$ & $(0.323)$ & $(0.264)$ & $(0.368)$ & $(0.369)$ & $(0.243)$ \\
\hline & \multirow[t]{2}{*}{ A year to two } & -0.0149 & -0.0216 & 0.00335 & -0.0455 & -0.122 & -0.0738 & 0.101 \\
\hline & & $(0.143)$ & $(0.174)$ & $(0.131)$ & $(0.257)$ & $(0.368)$ & $(0.162)$ & $(0.193)$ \\
\hline & \multirow{2}{*}{$\begin{array}{l}\text { More than two } \\
\text { years }\end{array}$} & 0.0262 & -0.0795 & -0.0617 & 0.068 & -0.0374 & -0.0733 & 0.0495 \\
\hline & & $(0.129)$ & $(0.139)$ & $(0.104)$ & $(0.231)$ & $(0.216)$ & $(0.130)$ & $(0.186)$ \\
\hline \multicolumn{2}{|c|}{ Number of observations } & 191 & 212 & 331 & 72 & 67 & 220 & 116 \\
\hline \multicolumn{9}{|c|}{$\begin{array}{l}\text { Source: Authors' estimations. } \\
\text { Notes: *, ** and } * * * \text { denote statistical significance at the } 10,5 \text { and } 1 \% \text { level, respectively. Results are robust to } \\
\text { heteroskedasticity. Weights provided along the survey used In the analysis. The coefficients on the other } \\
\text { explanatory variables not provided to save space, but available on request. Regional unemployment rate in the } \\
\text { year when the individual finished school is used as instrument for the unemployment spell. }\end{array}$} \\
\hline
\end{tabular}

\subsection{Does the number of previous unemployment spells matter?}

In this section, to our Table $\mathbf{6}$ and Table $\mathbf{8}$ we add a variable measuring the number of unemployment spells the person had before. By so doing, we capture the frequency of the unemployment spell aside its duration. In our sample, the variable takes a value from zero to a maximum of four. The results, presented in Table 10, suggest that with the addition of the number of previous unemployment spells, the power of the employment scar subsides. The reduction is more pronounced for the short-term spell group (and even vanishes for males). The number of unemployment spells is significant in all cases, suggesting a strong effect on employment opportunities. An additional unemployment spell reduces the probability to find gainful employment later by large $44 \%$, the effect being further stronger for females. The latter suggests that the number of unemployment spells is strongly negatively perceived by future employers. 
Table 10 - Results with the number of spells - Employment function

\begin{tabular}{|c|c|c|c|c|}
\hline \multicolumn{5}{|c|}{ Dependent variable: 1 = Person is employed now } \\
\hline & & & \multicolumn{2}{|c|}{ By gender } \\
\hline & & All & Males & Females \\
\hline & & (1) & (2) & (3) \\
\hline \multirow{2}{*}{\multicolumn{2}{|c|}{ Age (in years) }} & $0.0653^{* * *}$ & $0.0732 * * *$ & $0.0604 * * *$ \\
\hline & & $(0.008)$ & $(0.011)$ & $(0.012)$ \\
\hline \multirow{2}{*}{\multicolumn{2}{|c|}{ Experience (in years) }} & 0.0191 & 0.0425 & -0.0194 \\
\hline & & $(0.040)$ & $(0.048)$ & $(0.092)$ \\
\hline \multirow{2}{*}{\multicolumn{2}{|c|}{ Experience squared }} & -0.00258 & -0.00527 & 0.000947 \\
\hline & & $(0.005)$ & $(0.006)$ & $(0.016)$ \\
\hline \multirow{2}{*}{\multicolumn{2}{|c|}{ Gender (1=female) }} & -0.0405 & & \\
\hline & & $(0.044)$ & & \\
\hline \multirow{2}{*}{\multicolumn{2}{|c|}{ Secondary education }} & $0.252 * * *$ & $0.302 * * *$ & 0.123 \\
\hline & & $(0.056)$ & $(0.069)$ & $(0.089)$ \\
\hline \multirow{2}{*}{\multicolumn{2}{|c|}{ Tertiary education }} & 0.0279 & -0.0917 & 0.0405 \\
\hline & & $(0.075)$ & $(0.104)$ & $(0.107)$ \\
\hline \multirow{2}{*}{\multicolumn{2}{|c|}{ Marital status (1=married) }} & 0.0501 & -0.0606 & $0.144^{* *}$ \\
\hline & & $(0.050)$ & $(0.073)$ & (0.069) \\
\hline \multirow{2}{*}{\multicolumn{2}{|c|}{$\begin{array}{l}\text { Regional unemployment in } \\
2012\end{array}$}} & 0.00203 & 0.00116 & $0.00456 *$ \\
\hline & & $(0.002)$ & $(0.002)$ & $(0.003)$ \\
\hline \multirow{6}{*}{ 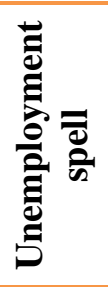 } & \multirow[t]{2}{*}{ Week to a year } & $-0.211 * * *$ & -0.137 & $-0.257 * *$ \\
\hline & & $(0.075)$ & $(0.099)$ & $(0.114)$ \\
\hline & \multirow[t]{2}{*}{ A year to two } & $-0.382 * * *$ & $-0.409 * * *$ & $-0.353 * * *$ \\
\hline & & $(0.055)$ & $(0.069)$ & $(0.083)$ \\
\hline & \multirow[t]{2}{*}{ More than two years } & $-0.587 * * *$ & $-0.632 * * *$ & $-0.542^{* * *}$ \\
\hline & & $(0.042)$ & $(0.052)$ & $(0.071)$ \\
\hline \multirow{2}{*}{\multicolumn{2}{|c|}{$\begin{array}{l}\text { Number of unemployment } \\
\text { spells }\end{array}$}} & $-0.440 * * *$ & $-0.434 * * *$ & $-0.418^{* * *}$ \\
\hline & & $(0.047)$ & $(0.048)$ & $(0.060)$ \\
\hline \multirow{2}{*}{\multicolumn{2}{|c|}{ Constant }} & $0.0598^{* * *}$ & $-0.211 * * *$ & -0.137 \\
\hline & & $(0.008)$ & $(0.075)$ & $(0.099)$ \\
\hline \multicolumn{2}{|c|}{ Observations } & 1,044 & 655 & 389 \\
\hline \multicolumn{5}{|c|}{$\begin{array}{l}\text { Source: Authors' estimations. } \\
\text { Notes: *, ** and *** denote statistical significance at the } 10,5 \text { and } 1 \% \text { level, } \\
\text { respectively. Results are robust to heteroskedasticity. Weights provided } \\
\text { along the survey used In the analysis. Regional unemployment rate in the } \\
\text { year when the individual finished school is used as instrument for the } \\
\text { unemployment spell. }\end{array}$} \\
\hline
\end{tabular}

Table $\mathbf{1 1}$ presents the results when the number of unemployment spells is added to the Mincer earnings function. They robustly suggest that the number of unemployment spells before does not matter for the current wage nor it affects that wage scar in any meaningful manner, as its $10 \%$-significance in the overall equation vanishes when split by gender. 
Table 11 - Results with the number of spells - Mincer function

\begin{tabular}{|c|c|c|c|c|}
\hline \multicolumn{5}{|c|}{ Dependent variable: Log of the gross hourly wage } \\
\hline & & \multicolumn{3}{|c|}{ By gender } \\
\hline & & All & Males & Females \\
\hline & & (1) & (2) & (3) \\
\hline \multirow{2}{*}{\multicolumn{2}{|c|}{ Age (in years) }} & $0.0361 * * *$ & $0.0295 * *$ & $0.0421 * *$ \\
\hline & & $(0.013)$ & $(0.012)$ & $(0.021)$ \\
\hline \multirow{2}{*}{\multicolumn{2}{|c|}{ Experience (in years) }} & 0.0486 & 0.0462 & -0.0195 \\
\hline & & $(0.045)$ & $(0.053)$ & $(0.109)$ \\
\hline \multirow{2}{*}{\multicolumn{2}{|c|}{ Experience squared }} & -0.00677 & -0.00565 & 0.00658 \\
\hline & & $(0.005)$ & $(0.006)$ & $(0.018)$ \\
\hline \multirow{2}{*}{\multicolumn{2}{|c|}{ Gender (1=female) }} & 0.0528 & & \\
\hline & & $(0.065)$ & & \\
\hline \multirow{2}{*}{\multicolumn{2}{|c|}{ Secondary education }} & 0.00917 & 0.00119 & -0.00617 \\
\hline & & $(0.069)$ & $(0.084)$ & $(0.109)$ \\
\hline \multirow{2}{*}{\multicolumn{2}{|c|}{ Tertiary education }} & $0.234 * *$ & $0.273 * *$ & 0.195 \\
\hline & & $(0.097)$ & $(0.118)$ & $(0.146)$ \\
\hline \multirow{2}{*}{\multicolumn{2}{|c|}{ Marital status (1=married) }} & $-0.213^{* * *}$ & $-0.189 * *$ & $-0.206^{*}$ \\
\hline & & $(0.075)$ & $(0.081)$ & $(0.110)$ \\
\hline \multirow{2}{*}{\multicolumn{2}{|c|}{ Regional unemployment in 2012}} & -0.00241 & -0.00123 & -0.00437 \\
\hline & & $(0.002)$ & $(0.003)$ & $(0.004)$ \\
\hline \multirow{6}{*}{ 苛 } & \multirow[t]{2}{*}{ Week to a year } & 0.161 & -0.0301 & 0.424 \\
\hline & & $(0.169)$ & $(0.096)$ & $(0.317)$ \\
\hline & \multirow[t]{2}{*}{ A year to two } & 0.0386 & 0.0299 & 0.0308 \\
\hline & & $(0.082)$ & $(0.098)$ & $(0.127)$ \\
\hline & \multirow[t]{2}{*}{ More than two years } & 0.00582 & 0.0209 & -0.0447 \\
\hline & & $(0.064)$ & $(0.082)$ & $(0.104)$ \\
\hline \multirow{2}{*}{\multicolumn{2}{|c|}{ Number of unemployment spells }} & $-0.104 *$ & -0.0765 & -0.125 \\
\hline & & $(0.062)$ & $(0.058)$ & $(0.107)$ \\
\hline \multirow{2}{*}{\multicolumn{2}{|c|}{ Constant }} & $3.653 * * *$ & $3.756^{* * *}$ & $3.663 * * *$ \\
\hline & & $(0.275)$ & $(0.296)$ & $(0.389)$ \\
\hline \multicolumn{2}{|c|}{ Observations } & 1,044 & 655 & 389 \\
\hline \multicolumn{5}{|c|}{$\begin{array}{l}\text { Source: Authors' estimations. } \\
\text { Notes: *, ** and }{ }^{* * *} \text { denote statistical significance at the } 10,5 \text { and } 1 \% \text { level, } \\
\text { respectively. Results are robust to heteroskedasticity. Weights provided along } \\
\text { the survey used In the analysis. Regional unemployment rate in the year when } \\
\text { the individual finished school is used as instrument for the unemployment } \\
\text { spell. }\end{array}$} \\
\hline
\end{tabular}

\subsection{Robustness checks}

In our methodological approach, we addressed the two concerns: the selection bias in the wage equation and the endogeneity of the unemployment spell. For robustness purposes we provide estimates of Heckman $(1976,1979)$ sample selection method as is done in e.g. Cooper (2014) and Gregory and Jukes (2001), despite some criticisms we exposed earlier. We add the regional unemployment rate at time of school-end as an exclusion restriction in the selection equation. Results presented in Table 12 largely corroborate our baseline findings and document absence of the wage scarring effect. 
Table 12 - Heckman sample-selection equation

\begin{tabular}{|c|c|c|c|}
\hline \multicolumn{4}{|c|}{ Dependent variable: Log of the gross hourly wage } \\
\hline & & $\begin{array}{l}\text { Outcome } \\
\text { equation }\end{array}$ & $\begin{array}{l}\text { Selection } \\
\text { equation }\end{array}$ \\
\hline & & (1) & $(2)$ \\
\hline \multirow{2}{*}{\multicolumn{2}{|c|}{ Age (in years) }} & $0.107 * * *$ & $0.126 * * *$ \\
\hline & & $(0.016)$ & $(0.014)$ \\
\hline \multirow{2}{*}{\multicolumn{2}{|c|}{ Experience (in years) }} & 0.00914 & -0.0353 \\
\hline & & $(0.059)$ & $(0.077)$ \\
\hline \multirow{2}{*}{\multicolumn{2}{|c|}{ Experience squared }} & -0.00729 & -0.00533 \\
\hline & & $(0.008)$ & $(0.012)$ \\
\hline \multirow{2}{*}{\multicolumn{2}{|c|}{ Gender (1=female) }} & 0.00384 & 0.113 \\
\hline & & $(0.070)$ & $(0.083)$ \\
\hline \multirow{2}{*}{\multicolumn{2}{|c|}{ Secondary education }} & 0.0491 & $0.360 * * *$ \\
\hline & & $(0.092)$ & $(0.101)$ \\
\hline \multirow{2}{*}{\multicolumn{2}{|c|}{ Tertiary education }} & $0.335^{* * *}$ & $0.285 * *$ \\
\hline & & $(0.106)$ & $(0.129)$ \\
\hline \multirow{2}{*}{\multicolumn{2}{|c|}{ Marital status (1=married) }} & $-0.236^{* * *}$ & -0.128 \\
\hline & & $(0.079)$ & $(0.097)$ \\
\hline \multirow{2}{*}{\multicolumn{2}{|c|}{ Regional unemployment in 2012}} & 0.00287 & \\
\hline & & $(0.003)$ & \\
\hline \multirow{6}{*}{ 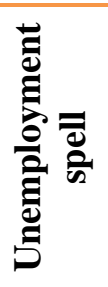 } & \multirow[t]{2}{*}{ Week to a year } & 0.122 & 0.106 \\
\hline & & $(0.102)$ & $(0.119)$ \\
\hline & \multirow[t]{2}{*}{ A year to two } & 0.107 & 0.044 \\
\hline & & $(0.125)$ & $(0.145)$ \\
\hline & \multirow[t]{2}{*}{ More than two years } & -0.111 & $-0.403 * * *$ \\
\hline & & $(0.111)$ & $(0.123)$ \\
\hline \multirow{2}{*}{\multicolumn{2}{|c|}{$\begin{array}{l}\text { Regional employment rates at the time of } \\
\text { finishing school }\end{array}$}} & & $-0.00640 * *$ \\
\hline & & & $(0.003)$ \\
\hline \multirow{2}{*}{\multicolumn{2}{|c|}{ Constant }} & 0.733 & $-3.958 * * *$ \\
\hline & & $(0.481)$ & $(0.341)$ \\
\hline \multicolumn{2}{|c|}{ Observations } & 1,217 & 1,217 \\
\hline
\end{tabular}

In Table 13 we provide some further robustness checks to our central estimates (Table 8, column 3) by cutting the age span of the sample (columns 1 and 2); and by adding the occupations (column 3). Note that for the latter case, we add the actual occupations of those who work and desired occupations of those who do not work where available. Results remain robust, i.e. the absence of the wage scar is further confirmed. 
Table 13 - Some further robustness checks

\begin{tabular}{|c|c|c|c|c|}
\hline \multicolumn{5}{|c|}{ Dependent variable: Log of the gross hourly wage } \\
\hline & & $\begin{array}{c}\text { Age span } \\
15-24\end{array}$ & $\begin{array}{c}\text { Age span } \\
20-29\end{array}$ & $\begin{array}{c}\text { Occupations } \\
\text { added }\end{array}$ \\
\hline & & (1) & $(2)$ & (3) \\
\hline \multirow{2}{*}{\multicolumn{2}{|c|}{ Age (in years) }} & 0.00274 & $0.0425 * * *$ & $0.0327 * *$ \\
\hline & & $(0.019)$ & $(0.014)$ & $(0.015)$ \\
\hline \multirow{2}{*}{\multicolumn{2}{|c|}{ Experience (in years) }} & -0.0313 & 0.0142 & -0.00363 \\
\hline & & $(0.106)$ & $(0.044)$ & $(0.048)$ \\
\hline \multirow{2}{*}{\multicolumn{2}{|c|}{ Experience squared }} & 0.00535 & -0.00356 & -0.00042 \\
\hline & & $(0.023)$ & $(0.005)$ & $(0.006)$ \\
\hline \multirow{2}{*}{\multicolumn{2}{|c|}{ Gender (1=female) }} & -0.0102 & 0.0464 & 0.0144 \\
\hline & & $(0.061)$ & $(0.068)$ & $(0.086)$ \\
\hline \multirow{2}{*}{\multicolumn{2}{|c|}{ Secondary education }} & 0.0133 & 0.00294 & -0.0468 \\
\hline & & $(0.082)$ & $(0.073)$ & $(0.097)$ \\
\hline \multirow{2}{*}{\multicolumn{2}{|c|}{ Tertiary education }} & $0.356 * *$ & $0.232 * *$ & -0.0879 \\
\hline & & $(0.139)$ & $(0.100)$ & $(0.158)$ \\
\hline \multirow{2}{*}{\multicolumn{2}{|c|}{ Marital status (1=married) }} & -0.0671 & $-0.211 * * *$ & $-0.254 * * *$ \\
\hline & & $(0.092)$ & $(0.075)$ & $(0.096)$ \\
\hline \multirow{2}{*}{\multicolumn{2}{|c|}{ Regional unemployment in 2012}} & -0.00034 & -0.00311 & $-0.00578^{*}$ \\
\hline & & $(0.003)$ & $(0.002)$ & $(0.003)$ \\
\hline \multirow{2}{*}{\multicolumn{2}{|c|}{ Armed forces }} & & & $0.629 * * *$ \\
\hline & & & & $(0.122)$ \\
\hline \multirow{2}{*}{\multicolumn{2}{|c|}{ Managers }} & & & -0.0241 \\
\hline & & & & $(0.356)$ \\
\hline \multirow{2}{*}{\multicolumn{2}{|c|}{ Professionals }} & & & $0.450 * * *$ \\
\hline & & & & $(0.152)$ \\
\hline \multirow{2}{*}{\multicolumn{2}{|c|}{ Technicians and associate professionals }} & & & $0.497 * *$ \\
\hline & & & & $(0.205)$ \\
\hline \multirow{2}{*}{\multicolumn{2}{|c|}{ Clerical support workers }} & & & $0.276^{*}$ \\
\hline & & & & $(0.165)$ \\
\hline \multirow{2}{*}{\multicolumn{2}{|c|}{ Service and sales workers }} & & & -0.045 \\
\hline & & & & $(0.089)$ \\
\hline \multirow{2}{*}{\multicolumn{2}{|c|}{ Skilled agricultural workers }} & & & 0.0102 \\
\hline & & & & $(0.168)$ \\
\hline \multirow{2}{*}{\multicolumn{2}{|c|}{ Craft and related trades workers }} & & & -0.0096 \\
\hline & & & & $(0.106)$ \\
\hline \multirow{2}{*}{\multicolumn{2}{|c|}{ Plant and machine operators }} & & & -0.123 \\
\hline & & & & $(0.103)$ \\
\hline \multicolumn{2}{|c|}{ Elementary occupations } & & & $\begin{array}{l}\text { Reference } \\
\text { category }\end{array}$ \\
\hline \multirow{6}{*}{ 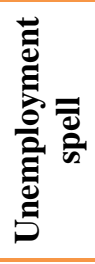 } & \multirow[t]{2}{*}{ Week to a year } & -0.00538 & 0.136 & 0.165 \\
\hline & & $(0.117)$ & $(0.167)$ & $(0.190)$ \\
\hline & \multirow[t]{2}{*}{ A year to two } & -0.0147 & 0.00418 & $-4.19 \mathrm{E}-03$ \\
\hline & & $(0.095)$ & $(0.084)$ & $(0.089)$ \\
\hline & \multirow[t]{2}{*}{ More than two years } & 0.0232 & -0.0271 & -0.0319 \\
\hline & & $(0.093)$ & $(0.067)$ & $(0.089)$ \\
\hline Const & & $4.228 * * *$ & $3.453^{* * *}$ & $3.832 * * *$ \\
\hline & & $(0.409)$ & $(0.326)$ & $(0.341)$ \\
\hline Obser & & 531 & 952 & 589 \\
\hline $\begin{array}{l}\text { Source } \\
\text { Notes: } \\
\text { robust } \\
\text { equati } \\
\text { the yec }\end{array}$ & $\begin{array}{l}\text { s. } \\
\text { statistical significance } \\
\text { Endogeneity considere } \\
\text { led along the survey use } \\
\text { finished school is used }\end{array}$ & $\begin{array}{l}0,5 \text { and } 1 \% \\
\text { ng the prec } \\
\text { analysis. } \\
\text { ument for }\end{array}$ & $\begin{array}{l}\text { evel, respect } \\
\text { ed unemploy } \\
\text { ional unem! }\end{array}$ & $\begin{array}{l}\text { ly. Results are } \\
\text { ent spell from } \\
\text { yment rate in } \\
\text { spell. }\end{array}$ \\
\hline
\end{tabular}




\section{Conclusions and policy recommendations}

The study aimed at contributing to the literature of youth unemployment and scarring by analyzing the phenomena in a context of a developing country with (extremely) high youth unemployment, using a novel methodological approach and newly available micro data. We first examined the factors that play major role in explaining the duration of the unemployment spell of young persons in Macedonia, and then assessed how the unemployment spell duration affected employment opportunities (the employment 'scarring' effect) and wage outcomes (the wage 'scarring' effect).

Methodologically, we first devised a model in which the unemployment spell is determined by individual and household characteristics and work attitudes and preferences. Discrete-time duration method was used to estimate this model. Then, we relied on a standard probit function to assess the employment scar and a Mincer earnings function to assess the wage scar. We repeatedly imputed missing wages to address the selection on observables, and used the regional unemployment rate when individual ended school as an instrument to resolve the selection on unobservables. The School to Work Transition Survey 2012 is used.

Our findings suggest that a combination of individual, socio-economic factors and working preferences and attitudes works to determine the unemployment experience of a young person and the probability of finding a job. Results suggest it is working preferences and attitudes to work and life that most affect the unemployment spell duration. This group of factors include: reservation wage, internships and career orientation in life. Socio-economic factors were found of secondary importance, where mainly father's education and family welfare were found significant (both of which can reflect the social networks of the parents, i.e. how likely are they to assist their child in finding a job). Only age is the individual factor that was found to have affected how long a young person in Macedonia stays unemployed.

Our results find strong evidence of a presence of employment scar: those young persons who stay unemployed over a longer period of time have lower chances to find a job afterwards. Results suggest that an individual with a short-term spell (week to a year) has lower probability of $28.4 \%$ to get employed than person with a spell of less than a week. The scar for individuals with medium-term and long-term spells are, respectively, $42.6 \%$ and $61.8 \%$. Hence, the scarring effect grows with the duration of the unemployment spell, i.e. the latter significantly undermines employment opportunities of youth, especially in the long run. Observed by gender, the employment scar was found stronger for females in the short-to-medium-term duration, and vice-versa for males. These results suggest that it is likely that with skills diminish with the unemployment spell duration, which then ruins employment opportunities, i.e. that our finding lend support to the human capital theory.

On the other hand, our study does not provide evidence for the existence of the wage scar. This implies that despite the difficulty in finding a job, once young persons manage to find a job, their wages are not 
significantly different because of the duration of the unemployment spell. This finding is in line with our predictions from section 2 for the low importance of the unemployment spell for subsequent wages, related to the low signaling value of the unemployment. It is also in line with some of the previous studies which tend to find evidence for the employment scar, but not the wage scar, especially in regions/countries with high unemployment.

Following the findings, one can draw several policy implications/conclusions towards reducing employment scar of young people:

- Avoid young people falling into unemployment at the exit from the education - offer internship programs (through active labor market programs), or some flexible forms of employment (for instance, trial work for a limited time period). This measure, though, may work best for tertiary educated individuals and for graduates from secondary vocational school.

- Further promote the wage subsidies programs for unemployed youth.

- Introduce a program "Quick start” for youth which will include a combination of services (for instance, job search training) and active program for every young person that is registered as unemployed for over a month and especially over a year.

- Improve career services at universities but also introduce mandatory career orientation to each student provided by the Public Employment Service (PES). Among others, this orientation should form/articulate the wage expectations of young people (and inform them better so that they can more realistically form their reservation wage).

- Design special work programs for young people while studying - only few of young persons in Macedonia work while studying as opposed to the practices of the Western countries. Government might develop some program of "mini” jobs for students to encourage them to find a job while studying.

- All newly-registered young unemployed should receive career guidance and employment counselling services to improve their capacity to navigate through the labor market.

- All newly-registered young unemployed should receive general training for work preparedness.

On the other hand, there are some important factors that affect the duration of unemployment spell of young people, which unfortunately cannot be influenced by government programs. These mainly include fathers' education and the wealth of the family. However, it also prompts for targeting the above measures to the at-risk young people which in this case include poorer young people and those with low education of the father (or parents in general). For them, for instance, the wage subsidies can be higher or of longer duration than the regular wage subsidy program. In addition, they can be entitled to more intense services by PES. Surely, the government may attempt to affect some outcomes in the long run, e.g. by improving the income of youth's parents. 


\section{References}

Arulampalam, W., Gregg, P. and Gregory, M. (2001) Unemployment Scarring. The Economic Journal, 111(475):577-584.

Becker, G.S. (1964) Human Capital: A theoretical and empirical analysis, with special reference to education. New York: National Bureau of Economic Research, General Series No. 80.

Blau, F. D., Kahn, L. M., Liu, A. Y. and Papps, K. L. (2013) The transmission of women’s fertility, human capital, and work orientation across immigrant generations, Journal of Population Economics, 26(2):405-435.

Box-Steffensmeier, J.M. and Bradford S. Jones (2004) Event History Modeling: A Guide for Social Scientists. Cambridge University Press.

Brada, J., Marelli, E. and Signorelli, M. (2014) Young People and the Labor Market: Key determinants and new evidence. Comparative Economic Studies, 56(4):556-566.

Cooper, D. (2014) The effect of unemployment duration on future earnings and other outcomes. Federal Reserve Bank of Boston, Working Papers: 13-8.

Cockx, B. and Picchio, M. (2012) Are Short-lived Jobs Stepping Stones to Long-Lasting Jobs? Oxford Bulletin of Economics and Statistics, 74(5): 646-675.

Cruces, G., Ham, A. and Viollaz, M. (2012) Scarring effects of Youth Unemployment and Informality: Evidence from Brazil. Centre for Distributive, Labor and Social Studies Working Paper, April, 2012.

Cunningham, W. and Salvagno, J.B. (2011) Youth Employment Transitions in Latin America. World Bank Policy Research Working Paper No. 5521.

Fares, J. and Tiongson, E. (2007) Youth Unemployment, Labor Market Transitions, and Scarring: Evidence from Bosnia and Herzegovina 2001-04. World Bank Policy Research Working Paper, No. 4183.

Fernandez, R. and Fogli, A. (2009) Culture: An Empirical Investigation of Beliefs, Work, and Fertility, American Economic Journal: Macroeconomics, 1(1):146-177.

Fougère, D., Kramarz, F. and Pouget, J. (2009) Youth Unemployment and Crime in France. Journal of the European Economic Association, 7(5):909-938.

Gasparini, L. and Tornarolli, L. (2009) Labor Informality in Latin America and the Caribbean: Patterns and Trends from Household Survey Microdata. Desarrollo y Sociedad No. 63.

Ghirelli, C. (2015) Scars of early non-employment for low educated youth: evidence and policy lessons from Belgium. IZA Journal of European Labor Studies, 4(1):1-34. 
Graham, JW., Olchowski, AE. and Gilreath TD (2007) How Many Imputations are Really Needed? Some Practical Clarifications of Multiple Imputation Theory. PrevSci, 8:206-213.

Gregg, P. (2001) The impact of youth unemployment on adult unemployment in the NCDS. Economics Journal, 111(475):626-653

Gregg, P. and Tominey, E. (2005) The Wage Scar from Youth Unemployment. Labour Economics, 12(4):487-509.

Gregory, M. and Jukes, R. (2001) Unemployment and Subsequent Earnings: Estimating Scarring Among British Men 1984-94. Economic Journal, 111(475):607-625.

Heckman, J. (1976) The Common Structure of Statistical Models of Truncation, Sample Selection and Limited Dependent Variables and a Simple Estimator for Such Models. Annals of Economic Social Measurement, 5(4):475-492.

Heckman, J. (1979) Sample Selection Bias as a Specification Error. Econometrica, 47:153- 163.

Hensher, D.A. and F.L. Mannering (1994) Hazard-based duration models and their application to transport analysis. Transport Reviews, 14(1):63-82.

Hosmer D.W., Lemeshow S., and May S., (2008) Applied Survival Analysis: Regression Modeling of Timeto- Event Data, Wiley.

Kiefer, N.M. (1988) Economic duration data and hazard functions. Journal of Economic Literature, 27:646-679.

Kollmann, R. (1994) The duration of unemployment as a signal. Economic Letters, 45:373-377.

Lancaster, T. (1990). The Economic Analysis of Transition Data. Cambridge: Cambridge University Press.

Lebwel, A. (2012). Using Heteroskedasticity to Identify and Estimate Mismeasured and Endogenous Regressor Models. Journal of Business \& Economic Statistics, 30(1).

Leung, SF. and Yu, S. (1996) On the choice between sample selection and two-part models. Journal of Economics, 72(1-2):197-229.

Lockwood, B. (1991) Information externalities in the labor market and the duration of unemployment. Review of Economic Studies, 58(4):733-753.

Lupi, C. and Ordine, P. (2002) Unemployment scarring in high unemployment regions. Economics Bulletin, 10(2):1-8.

Mooi-Reci, I. and Ganzeboom, H. B. (2014) Unemployment scarring by gender: Human capital depreciation or stigmatization? Longitudinal evidence from the Netherlands, 1980-2000. Social Science Research, 52:642-658. 
Muthén, B.O., and Masyn, K. (2005). Discrete-time survival mixture analysis. Journal of Educational and Behavioral Statistics, 30(1):27-58.

Neal, D. (2004) The Measured Black-White Wage Gap among Women is Too Small. Journal of Political Economy, 112:S1-S28.

Nekby, L and Rödin, M. (2009) Acculturation identity and employment among second and middle generation immigrants. Journal of Economic Psychology, 31(2010):35-50.

Nilsen, Ø.A. and Reiso, K.H. (2011) Scarring Effects of Unemployment. IZA Discussion Paper No. 6198.

Olivetti, C. and Petrongolo B. (2008) Unequal Pay or Unequal Employment? A Cross-Country Analysis of Gender Gaps. Journal of Labor Economics, 26(4):621-654.

Petreski, M., Mojsoska-Blazevski, N. and Petreski, B. (2014) Gender wage gap when women are highly inactive: Evidence from repeated imputations with Macedonian data. Journal of Labor Research. 35(4):393-411.

Pina-Sánchez, J., Koskinen, J. and Plewis, I. (2013) Implications of Retrospective Measurement Error in Event History Analysis. Metodología de Encuestas, 15:5-25.

Raphael, S. and Winter-Ebmer, R. (2001) Identifying the Effect of Unemployment on Crime. Journal of Law and Economics, 44(1):259-283.

Ryan, R. (2001) The School-to-Work Transition: A Cross-National Perspective. Journal of Economic Literature, 39(1):34-92.

Schmillen, A. and Umkehrer, M. (2013) The scars of youth: effects of early-career unemployment on future unemployment experience. IAB Discussion Paper 201306. IAB, Nurnberg, Germany.

Spence, M. (1973) Job Market Signaling. The Quarterly Journal of Economics, 87(3):355-374.

Wooldridge, J.M. (2002). Econometric Analysis of Cross Section and Panel Data. London: The MIT Press. 


\section{Appendix 1 - Variables description and descriptives}

Table 14 - Variables definition

\begin{tabular}{|c|c|}
\hline Variables & Description \\
\hline \multirow[t]{3}{*}{ Unemployment duration } & $\begin{array}{l}\text { Discrete variable taking values } 1 \text { (no unemployment spell) to } 8 \\
\text { (two and more years). }\end{array}$ \\
\hline & $\begin{array}{l}\text { It has been created by merging two questions available in the } \\
\text { survey: "For how long have you been seeking for a job before you } \\
\text { have found the current one?" and "For how long are you now } \\
\text { without a job and have been actively searching for such?” As the } \\
\text { two are mutually exclusive, the aggregate unemployment spell } \\
\text { duration variable has been created by their simple sum. For the } \\
\text { purpose of the modelling a dummy variable has been created also, } \\
\text { to distinguish the cases where the variable is censored (the person } \\
\text { is still searching for a job) out of those where it is not censored } \\
\text { (the person is already in employment). }\end{array}$ \\
\hline & $\begin{array}{l}\text { Four dummies have been created out of this variable: } \\
\begin{aligned} &- 1=\text { Unemployment spell duration of less than a week, } 0 \\
&=\text { otherwise } \\
&- 1=\text { Unemployment spell duration of between a week and } \\
& \text { a year (short-term duration), } 0=\text { otherwise }\end{aligned} \\
-\quad \begin{array}{l}1=\text { Unemployment spell duration of between a year and } \\
\text { two years (medium-term duration), } 0=\text { otherwise }\end{array} \\
\begin{array}{l}1=\text { Unemployment spell duration of more than two years } \\
\text { (long-term duration), } 0=\text { otherwise }\end{array}\end{array}$ \\
\hline Number of spells before & $\begin{array}{l}\text { The number of spells of unemployment the person had before the } \\
\text { current employment / the current moment }\end{array}$ \\
\hline Employment & $1=$ the person is in employment now, $0=$ otherwise \\
\hline Log wage & Logged value of reported gross hourly wage \\
\hline \multicolumn{2}{|r|}{ Individual factors } \\
\hline Age & Reported age of the person \\
\hline Gender & $1=$ female; $0=$ male \\
\hline Experience & $\begin{array}{l}\text { Total working experience of the person in wage employment, self- } \\
\text { employment or an unpaid family worker, in years }\end{array}$ \\
\hline Marital status & 1 = married; 0 = non-married (single, divorced, widowed, other) \\
\hline Education level & $\begin{array}{l}\text { Highest completed level of education, represented through three } \\
\text { dummies: primary or less; secondary and tertiary education }\end{array}$ \\
\hline Occupations & $\begin{array}{l}\text { Actual occupations of those who work and desired occupations of } \\
\text { those who do not work (ISCO08 classification, one digit) }\end{array}$ \\
\hline \multicolumn{2}{|r|}{ Socio-economic factors } \\
\hline Number of children in the household & Continuous variable: “How many children do you have?” \\
\hline Educational level of parents & $\begin{array}{l}\text { Highest reported education of mother and father. Discrete variable } \\
\text { on scale 1-no schooling, to 6-post-graduate studies, recoded to } \\
\text { three dummies per parent: primary or less; secondary and tertiary } \\
\text { education }\end{array}$ \\
\hline Financial situation of the household & $\begin{array}{l}\text { Quintile distribution of income based on the reported total income } \\
\text { of the household per month }\end{array}$ \\
\hline \multicolumn{2}{|c|}{ Working preferences and attitudes } \\
\hline Log reservation wage & $\begin{array}{l}\text { Log of the reported minimum level of income per month below } \\
\text { which a person would not accept a job }\end{array}$ \\
\hline Search intensity & $\begin{array}{l}\text { The number of applications for jobs before employment or before } \\
\text { the moment of the interview }\end{array}$ \\
\hline
\end{tabular}




\begin{tabular}{|c|c|}
\hline Attended internships during schooling & 1=At least one internship while studying, $0=$ otherwise \\
\hline Career attitude during schooling & $\begin{array}{l}1=\text { if the goal of an individual today was to be successful at work, } \\
0=\text { otherwise (have more leisure time, have lots of money, have } \\
\text { good family life, uphold religious thoughts, make contribution to } \\
\text { the society, etc.) }\end{array}$ \\
\hline \multirow[t]{2}{*}{ Career attitude now } & $\begin{array}{l}1=\text { if the goal of an individual today was to be successful at work, } \\
0=\text { otherwise (have more leisure time, have lots of money, have } \\
\text { good family life, uphold religious thoughts, make contribution to } \\
\text { the society, etc.) }\end{array}$ \\
\hline & Regional unemployment \\
\hline \multirow[t]{3}{*}{$\begin{array}{l}\text { Regional unemployment rate at the } \\
\text { time when the person finished school }\end{array}$} & $\begin{array}{l}\text { Unemployment rate for each of the eight planning regions in } \\
\text { Macedonia. }\end{array}$ \\
\hline & $\begin{array}{l}\text { The rate is the actual one for the period 2008-2012, obtained from } \\
\text { the Regional statistics of the State Statistical Office. For the period } \\
\text { 1993-2007, these rates are not available and hence have been } \\
\text { obtained by interpolating the trends, as well by considering the } \\
\text { weighted average each year to produce the national annual } \\
\text { unemployment rate. }\end{array}$ \\
\hline & $\begin{array}{l}\text { The extrapolation is based on the observation that prior to } 2008 \\
\text { there has been no regional economic policy pursued and hence it } \\
\text { is likely that the trends of the regional rates were mimicking the } \\
\text { trend of the national unemployment rate. }\end{array}$ \\
\hline Regional unemployment rate in 2012 & $\begin{array}{l}\text { Unemployment rate for each of the eight planning regions in } \\
\text { Macedonia in } 2012 .\end{array}$ \\
\hline
\end{tabular}


Table 15 - Descriptive statistics

\begin{tabular}{|llllrr|}
\hline \multicolumn{1}{c}{ Variable } & \multicolumn{1}{c}{ Obs } & \multicolumn{1}{c}{ Mean } & Std.Dev & Min & Max \\
\hline Age (in years) & 1262 & 23.80 & 3.42 & 15 & 29 \\
\hline Experience (in years) & 1262 & 0.39 & 1.30 & 0 & 10.33 \\
\hline Gender (1=female) & 1262 & 0.52 & 0.50 & 0 & 1 \\
\hline Secondary education & 1262 & 0.17 & 0.37 & 0 & 1 \\
\hline Tertiary education & 1262 & 0.23 & 0.42 & 0 & 1 \\
\hline Marital status (1=married) & 1262 & 0.30 & 0.73 & 0 & 6 \\
\hline Number of children in the household & 1262 & 0.53 & 0.50 & 0 & 1 \\
\hline The father has secondary education & 1262 & 0.10 & 0.29 & 0 & 1 \\
\hline The father has tertiary education & 1262 & 0.40 & 0.49 & 0 & 1 \\
\hline The mother has secondary education & 1262 & 0.07 & 0.25 & 0 & 1 \\
\hline The mother has secondary education & 1262 & 3.36 & 1.30 & 1 & 5 \\
\hline Household's financial situation & 1262 & 3.57 & 0.91 & 0 & 4 \\
\hline Career orientation today (1=yes) & 1262 & 0.44 & 0.50 & 0 & 1 \\
\hline $\begin{array}{l}\text { Career orientation while studying } \\
\text { (1=yes) }\end{array}$ & 1262 & 0.90 & 0.29 & 0 & 1 \\
\hline $\begin{array}{l}\text { Pursued at least one internship while } \\
\text { studying (1=yes) }\end{array}$ & 1262 & 0.19 & 0.39 & 0 & 1 \\
\hline Log of the reservation wage & 1262 & 3.16 & 4.40 & 0 & 10.46 \\
\hline $\begin{array}{l}\text { The number of jobs applied before } \\
\text { current job }\end{array}$ & 1262 & 0.80 & 3.30 & 0 & 60 \\
\hline $\begin{array}{l}\text { Regional unemployment rate at the time } \\
\text { of finishing school }\end{array}$ & 1221 & 36.01 & 14.30 & 9.3 & 66.09 \\
\hline Regional unemployment rate in 2012 & 1262 & 33.99 & 12.50 & 13.80 & 52.8 \\
\hline Unemployment spell (ordered variable) & 1262 & 5.73 & 2.44 & 1 & 8 \\
\hline $\begin{array}{l}\text { Unemployment spell (1 = less than a } \\
\text { week) }\end{array}$ & 1270 & 0.19 & 0.39 & 0 & 1 \\
\hline $\begin{array}{l}\text { Unemployment spell (1 = between a } \\
\text { week and a year) }\end{array}$ & 1270 & 0.28 & 0.45 & 0 & 1 \\
\hline $\begin{array}{l}\text { Unemployment spell (1 = between one } \\
\text { and two years) }\end{array}$ & 1270 & 0.13 & 0.34 & 0 & 1 \\
\hline $\begin{array}{l}\text { Unemployment spell (1 = more than two } \\
\text { years) }\end{array}$ & 1270 & 0.39 & 0.49 & 0 & 1 \\
\hline Number of spells before & 1262 & 0.77 & 0.63 & 0 & 4 \\
\hline Employed (1=employed) & 1262 & 0.59 & 0.49 & 0 & 1 \\
\hline Unemployed (1=unemployed) & 1262 & 0.41 & 0.49 & 0 & 1 \\
\hline Log of the hourly wage & 365 & 4.42 & 0.52 & 3.26 & 7.09 \\
\hline Source: SWTS 2012 & & & & \\
\hline
\end{tabular}




\section{Appendix 2 - Identification tests' statistics}

Two obvious drawbacks of the methodological design we use herein are: i) the fact that we cannot produce the identification test statistics; and ii) the fact that we use one instrument for three dummies, despite they refer to one single phenomenon - unemployment spell. However, to get a sense for the possibility of under- or weak-identification of our models as well for the validity of the over-identifying restrictions, we utilize the method of Lewbel (2012). It is a method used in applications where other sources of identification such as instrumental variables are not available, as is the case here. Within the method, identification comes from a heteroskedastic covariance restriction that is shown to be a feature of many models of endogeneity or mis-measurement.

Table 16 presents the results for both the employment and the Mincer function. In the latter case, we should note that the multiple imputed datasets are treated as a single dataset, as Lewbel's method (as others IV methods) is not technically feasible with repeated imputation. The second-stage results are appealing and comparable to those of Table $\mathbf{6}$ and Table 8. The table gives the F-statistics and the Angrist-Pischke test of excluded instruments of the first-stage regressions (three of them, one for each endogenous regressor); they suggest that the set of instruments used - the one we have on disposal, as well the internally generated instruments - is fine. Similarly, the under- and weak-identification tests, as well the Hansen test in the second stage provide sufficient evidence that we do not have problems with the identification, thus providing support to the results presented in the main text. 
Table 16 -Employment function with Lebwel's (2012) IV estimator

\begin{tabular}{|c|c|c|}
\hline & $\begin{array}{l}\text { Dependent } \\
\text { variable: } 1= \\
\text { Person is } \\
\text { employed now }\end{array}$ & $\begin{array}{l}\text { Dependent } \\
\text { variable: Log of the } \\
\text { gross hourly wage }\end{array}$ \\
\hline & $(1)$ & (2) \\
\hline \multirow[t]{2}{*}{ Age (in years) } & $0.0303 * *$ & $0.0227 * * *$ \\
\hline & $(0.015)$ & $(0.005)$ \\
\hline \multirow[t]{2}{*}{ Experience (in years) } & -0.0331 & -0.026 \\
\hline & $(0.028)$ & $(0.026)$ \\
\hline \multirow[t]{2}{*}{ Experience squared } & 0.00258 & 0.003 \\
\hline & $(0.004)$ & $(0.003)$ \\
\hline \multirow[t]{2}{*}{ Gender (1=female) } & $-0.0484^{*}$ & 0.001 \\
\hline & $(0.027)$ & $(0.024)$ \\
\hline \multirow[t]{2}{*}{ Secondary education } & $0.119 * * *$ & $-0.0660 * *$ \\
\hline & $(0.036)$ & $(0.030)$ \\
\hline \multirow[t]{2}{*}{ Tertiary education } & $0.0973 * *$ & $0.164 * * *$ \\
\hline & $(0.049)$ & $(0.048)$ \\
\hline \multirow[t]{2}{*}{ Marital status (1=married) } & $0.150^{* * *}$ & $-0.149 * * *$ \\
\hline & $(0.035)$ & $(0.030)$ \\
\hline \multirow[t]{2}{*}{ Regional unemployment rate in 2012} & $0.00184 *$ & $-0.00191^{*}$ \\
\hline & $(0.001)$ & $(0.001)$ \\
\hline \multirow[t]{2}{*}{ Week to a year } & $-0.483 * * *$ & -0.088 \\
\hline & $(0.075)$ & $(0.075)$ \\
\hline \multirow[t]{2}{*}{ A year to two } & $-0.669 * * *$ & -0.087 \\
\hline & $(0.112)$ & $(0.086)$ \\
\hline \multirow[t]{2}{*}{ More than two years } & $-0.713^{* * *}$ & -0.083 \\
\hline & $(0.070)$ & $(0.078)$ \\
\hline $\begin{array}{l}\text { Underidentification test } \\
\text { Kleibergen-Paap rk LM statistic (p- } \\
\text { value) }\end{array}$ & 0.0000 & 0.0000 \\
\hline \multicolumn{3}{|l|}{ Weak identification test } \\
\hline $\begin{array}{l}\text { Overidentification test of all } \\
\text { instruments (p-value) }\end{array}$ & 0.2807 & 0.4598 \\
\hline \multicolumn{3}{|c|}{ Tests on the first-stages (three first-stage equations) } \\
\hline $\begin{array}{l}\text { Test of excluded instruments (F- } \\
\text { prob) }\end{array}$ & $\begin{array}{l}0.0000 \\
0.0000 \\
0.0000\end{array}$ & $\begin{array}{l}0.0000 \\
0.0000 \\
0.0000\end{array}$ \\
\hline $\begin{array}{l}\text { Angrist-Pischke multivariate } F \text { test } \\
\text { of excluded instruments }\end{array}$ & $\begin{array}{l}0.0000 \\
0.0000 \\
0.0000\end{array}$ & $\begin{array}{l}0.0000 \\
0.0000 \\
0.0000\end{array}$ \\
\hline \multicolumn{3}{|c|}{$\begin{array}{l}\text { Source: Authors' estimations. } \\
\text { Notes: *, ** and } * * * \text { denote statistical significance at the } 10,5 \text { and } 1 \% \text { level, } \\
\text { respectively. }\end{array}$} \\
\hline
\end{tabular}

